\title{
Mesenchymal stem cell transplantation as an effective treatment strategy for ischemic stroke in Asia: a meta-analysis of controlled trials
}

This article was published in the following Dove Press journal:

Therapeutics and Clinical Risk Management

\section{Ping Xue \\ Min Wang \\ Guanhua Yan}

Department of Neurology, Liaocheng People's Hospital, Liaocheng Clinical School of Taishan Medical University, Liaocheng, People's Republic of China

Correspondence: Guanhua Yan Department of Neurology, Liaocheng People's Hospital, Liaocheng Clinical School of Taishan Medical University, No 67 Dongchang West Road, Liaocheng 252000, Shandong, People's Republic of China Tel +86 I52 66889065 Email guahuayan65@I63.com
Objective: The aim of this study was to evaluate the efficacy and safety of the mesenchymal stem cell (MSC) therapy in patients with ischemic stroke (IS).

Materials and methods: Clinical trials involved in this research were searched from PubMed, Web of Science, Cochrane Library, Embase, Wanfang and CNKI database. Therapeutic effects of MSC therapy were assessed according to National Institutes of Health Stroke Scale (NIHSS), Barthel index (BI), Fugl-Meyer Assessment (FMA) and Functional Independence Measure (FIM), and its safety was evaluated based on adverse events.

Results: This research covered 23 trials including 1,279 IS patients. Based on our analysis, the overall condition of IS patients significantly improved after MSC therapy, indicated by decreased NIHSS and increased BI, FMA and FIM scores. Our analysis also showed that the treatment effects in the MSC transplantation group were superior to those in the control group (routine medication therapy) with statistical significance for NIHSS ( 1 month after therapy: odds ratio $[\mathrm{OR}]=-1.92, \mathrm{CI}=-3.49$ to $-0.34, P=0.02 ; 3$ months after therapy: $\mathrm{OR}=-2.65, \mathrm{CI}=-3.40$ to $-1.90, P<0.00001)$, BI ( 1 month after therapy: $\mathrm{OR}=0.99, \mathrm{CI}=0.19-1.79, P=0.02 ; 6$ months after therapy: $\mathrm{OR}=10.10, \mathrm{CI}=3.07-17.14, P=0.005)$, FMA ( 3 months after therapy: $\mathrm{OR}=10.20$, $\mathrm{CI}=3.70-16.70, P=0.002$; 6 months after therapy: $\mathrm{OR}=10.82, \mathrm{CI}=6.45-15.18, P<0.00001)$ and FIM ( 1 month after therapy: $\mathrm{OR}=15.61, \mathrm{CI}=-0.02$ to $31.24, P=0.05 ; 6$ months after therapy: $\mathrm{OR}=16.56, \mathrm{CI}=9.06-24.06, P<0.0001)$. No serious adverse events were reported during MSC therapy.

Conclusion: MSC therapy is safe and effective in treating IS by improving the neurological deficits, motor function and daily life quality of patients.

Keywords: mesenchymal stem cells, routine medication, ischemic stroke, meta-analysis

\section{Introduction}

Stroke is the most lethal and second most incident disease, together with cancer and cardiovascular disease. ${ }^{1,2}$ Ischemic stroke (IS) and intracerebral hemorrhage account for about $85 \%$ and $15 \%$, respectively, of all stroke events. ${ }^{3}$ The main pathological manifestation of IS is temporary brain tissue ischemia. ${ }^{1}$ Ischemia results in reduced neuron number and interrupted neural axon network, and formation of a defected environment around the ischemic region, which prohibits brain self-healing, eventually resulting in the permanent loss of nerve tissue or disabled brain function. ${ }^{1,4,5}$ Over 50,000,000 people are suffering from IS of various degrees in the world. ${ }^{6}$ The annual mortality rate is close to $10 \%$, and nearly $50 \%$ of stroke survivors are left with disabling sequelae. ${ }^{1,2,4}$ Poststroke rehabilitation therapy is scant, and currently the most efficient medicine for IS in clinical settings is tissue plasminogen activator. ${ }^{1,7}$ 
However, it functions mainly at the early stage of ischemia with a short time window, which may increase the risk of cerebral hemorrhage, and therefore, its clinical application is severely limited. ${ }^{7}$

Stem cell therapy, using hematopoietic stem cells (HSCs), ${ }^{8,9}$ neural stem cells (NSCs), ${ }^{10,11}$ endothelial progenitor cells (EPCs) ${ }^{12}$ and other types of stem cells, ${ }^{13,14}$ was considered a promising treatment for IS as it may reduce injury and promote rehabilitation after stroke. Mesenchymal stem cells (MSCs) are derived from mesoderm and have the capacity of regeneration and differentiation. MSCs can differentiate into various lineages such as NSCs, which can further differentiate into neurons, astrocytes, oligodendrocytes and so on, ${ }^{4,15,16}$ with low immunogenicity and high histocompatibility. ${ }^{1,15}$ Compared with other types of stem cells, such as NSCs, EPCs and HSCs, MSCs are more accessible as they can be easily obtained from umbilical cord, bone marrow, fat and other tissues, and can proliferate rapidly in vitro with little ethical constraints. ${ }^{15}$ Preliminary preclinical studies using MSCs to treat IS have shown beneficial effects. ${ }^{17-19}$ In animal models, researchers found the transplanted cells migrated to lesions, secreted neurotrophic factors, remitted inflammatory response and promoted plasticity and revascularization thereby minimizing the damage. ${ }^{18-20}$

Although both preclinical studies and studies with experimental models regarding MSC transplantation therapies for IS have been carried out, ${ }^{17-19}$ the clinical application of MSCs still has a long way to go due to its unverified safety and therapeutic effects. To address this issue, we conducted a meta-analysis of published clinical trials treating IS with MSCs, to provide scientific references for upcoming research and future clinical application.

\section{Materials and methods}

\section{Search strategy and selection criteria}

Studies were identified from PubMed, Web of Science, Cochrane Library, Embase, Wanfang and CNKI database, with key terms ("mesenchymal stem cells" or "MSC") and ("ischemic stroke" or "cerebral infarction" or "cerebral ischemia" or "brain ischemia"), without language restriction. The last search was performed in October 2017.

Studies were included if they fulfilled the following inclusion criteria: case-controlled trials involving IS patients; participants were diagnosed with IS and without malignant tumor, pregnancy and lactation; and patients in the experimental group received both MSC transplantation and IS routine treatment (RT; including conventional medical therapy and rehabilitation training treatment) combined therapy, and those in control group were treated by RT alone.

\section{Data extraction and quality assessment}

All data collection and extraction were performed by two authors (PX and MW) independently. The following information was summarized: author's names, years of publication, locations, type of IS, samples sizes, patients' ages, study parameter types, therapeutic regimens, administration routes, MSC dosages and adverse events during the MSC therapy. Trials' quality was assessed for risk of bias following the instruction of Cochrane Handbook. ${ }^{21}$

\section{Outcome definition}

Treatment efficacy was assessed in terms of National Institutes of Health Stroke Scale (NIHSS), Barthel index (BI), Fugl-Meyer Assessment (FMA) and Functional Independence Measure (FIM). The frequencies of adverse events were gathered and assessed for MSC therapy safety.

\section{Statistical analysis}

This meta-analysis was performed using Review Manager 5.3 (Cochrane Collaboration). The therapeutic efficacy was evaluated by odds ratio (OR) and presented with $95 \%$ CI. $P<0.05$ indicates differences with statistical significance. The appropriate analysis model was determined by analyzing the heterogeneity between trials by Cochran's $Q$ test. $^{22}$ Studies with $I^{2}<50 \%$ or $P>0.1$ were considered homogenous.

Publication bias was evaluated based on funnel plots. Sensitivity analysis on subgroups was also performed to assess the impact of MSC types, cell administration methods and patients' characteristics on clinical outcomes.

\section{Results}

\section{Search results}

A total of 2,998 articles were initially identified, and 2,921 were excluded for lacking clinical trials $(n=2,693)$, duplication and repetition $(n=177)$ or being unrelated $(n=51)$. The later detailed assessment further excluded 18 articles with insufficient data, 23 reviews or case reports or meta-analyses and 13 articles without control group. A total of 23 trials ${ }^{23-45}$ with 1,279 IS patients were finally identified meeting the restrict inclusion criteria of this research (Figure 1).

\section{Study and patient characteristics}

After selection, all included trials were found to have been conducted in Asia. Two studies were conducted in Korea, ${ }^{23,35}$ 


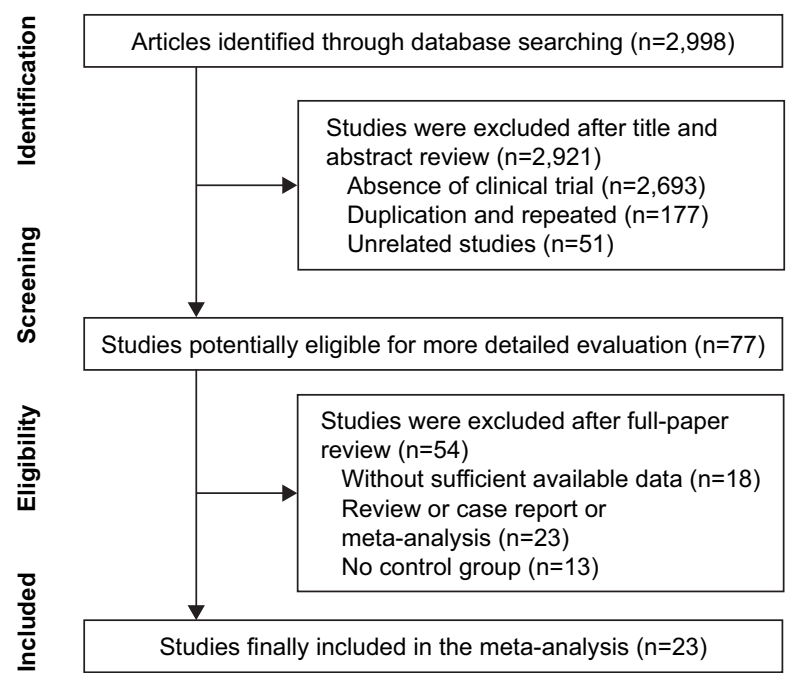

Figure I Flow diagram of the selection process.

two in India ${ }^{24,25}$ and the rest of the included studies in China. MSCs were obtained from bone marrow in 18 studies, ${ }^{23-30,32}$ 35-37,40-45 from umbilical cord in three studies ${ }^{33,34,38}$ and from umbilical cord blood in two studies. ${ }^{31,39}$ Cells were administered through peripheral vein in 14 studies, ${ }^{23-27}$,
$30,32,34,35,37,40-43$ subarachnoid in five studies, ${ }^{28,29,36,44,45}$ intrathecal in three studies ${ }^{31,33,39}$ and intracarotid artery in one study. ${ }^{38}$ In total, 625 IS patients accepted MSC and RT combined therapy, and 654 patients were treated by RT alone. Detailed information about the involved studies and participants is summarized in Tables 1 and 2.

\section{Quality assessment}

Bias risk of involved trials is shown in Figure 2. Sixteen studies were determined as low risk, five researches were not truly randomized controlled trials and the other two studies did not have clear illustration of randomization procedures. Seven trials did not provide clear description of allocation and performance concealment. All the included studies were free of detection risk. Three trials missing the follow-up study were considered as high risk, and one study with selective reporting was considered as unclear risk.

\section{Therapeutic efficacy assessments Effectiveness of MSCs assessed by the NIHSS score} The analysis of involved trials showed that after MSC therapy, the NIHSS score was reduced in the first, second,

Table I Clinical information from the eligible trials in the meta-analysis

\begin{tabular}{|c|c|c|c|c|c|c|}
\hline \multirow{2}{*}{$\begin{array}{l}\text { Included } \\
\text { studies }\end{array}$} & \multirow[t]{2}{*}{ Country } & \multirow{2}{*}{$\begin{array}{l}\text { Type of } \\
\text { stroke: acutel } \\
\text { chronic }\end{array}$} & \multirow{2}{*}{$\begin{array}{l}\text { Patients: } \\
\text { control/ } \\
\text { experimental }\end{array}$} & \multicolumn{2}{|c|}{ Age (years) } & \multirow{2}{*}{$\begin{array}{l}\text { Parameter } \\
\text { types }\end{array}$} \\
\hline & & & & Control & Experimental & \\
\hline Bang et $\mathrm{al}^{23}$ & Korea & Acute & $25 / 5$ & ND & ND & $\mathrm{BI}$ \\
\hline Bhasin et $\mathrm{al}^{24}$ & India & Chronic & $20 / 20$ & $45.2 \pm 11.8$ & $45.1 \pm 12.1$ & FMA, BI \\
\hline Bhasin et $\mathrm{al}^{25}$ & India & Chronic & $6 / 6$ & $46.5 \pm 6.3$ & $42 \pm 9.3$ & FMA, BI, AE \\
\hline Cai et $\mathrm{al}^{26}$ & China & Chronic & $2|/ 2|$ & $62.7 \pm 6.9$ & $61.4 \pm 6.7$ & FMA, FIM, BI \\
\hline Cheng et $\mathrm{al}^{27}$ & China & Acute & $18 / 18$ & $68.1 \pm 2.5$ & $69.1 \pm 1.2$ & FIM, BI \\
\hline Chen et $\mathrm{a}^{28}$ & China & ND & $43 / 43$ & ND & ND & FMA, FIM \\
\hline Chen et $\mathrm{al}^{29}$ & China & ND & $30 / 30$ & $57.4 \pm 9.6$ & $49.3 \pm 20.8$ & NIHSS \\
\hline Deng et $\mathrm{al}^{30}$ & China & ND & $15 / 15$ & ND & ND & NIHSS \\
\hline Feng et $\mathrm{al}^{3 \mathrm{I}}$ & China & ND & $50 / 50$ & $60.2 \pm 11.8$ & $61.4 \pm 11.3$ & NIHSS \\
\hline $\mathrm{He}^{32}$ & China & ND & $18 / 20$ & $54.3 \pm 8.7$ & $56.4 \pm 7.9$ & NIHSS, BI \\
\hline Hu et $\mathrm{al}^{33}$ & China & ND & $60 / 60$ & $59.2 \pm 13.8$ & $60.8 \pm 15.2$ & FMA, FIM \\
\hline Ji et $\mathrm{al}^{34}$ & China & ND & $60 / 60$ & ND & ND & FMA, BI \\
\hline Lee et $\mathrm{al}^{35}$ & Korea & Acute & $36 / 16$ & $64.9 \pm 14.5$ & $64.0 \pm 11.6$ & $\mathrm{AE}$ \\
\hline Liu et $\mathrm{al}^{36}$ & China & ND & $29 / 29$ & $56.9 \pm 4.4$ & $55.3 \pm 3.6$ & NIHSS, FMA, BI \\
\hline Meng et $\mathrm{al}^{37}$ & China & ND & $30 / 30$ & $52.9 \pm 8.3$ & $52.7 \pm 7.9$ & FMA, FIM \\
\hline Shen $^{38}$ & China & Acute & $16 / 16$ & ND & $52 \pm 10.4$ & FIM \\
\hline Song et $\mathrm{al}^{39}$ & China & ND & $28 / 28$ & 65.4 & 63.2 & NIHSS \\
\hline Sun et $\mathrm{al}^{40}$ & China & Acute & $22 / 20$ & $58.9 \pm 7.4$ & $57.8 \pm 8.9$ & NIHSS, BI \\
\hline Sun et $\mathrm{al}^{41}$ & China & ND & $15 / 20$ & $30.9 \pm 16.9$ & $29.5 \pm 9.4$ & FMA \\
\hline Tsang et $\mathrm{al}^{42}$ & Hong Kong & Chronic & $4 / 5$ & 51.5 & 53.4 & FIM, BI, AE \\
\hline Wang et $\mathrm{al}^{43}$ & China & ND & $60 / 60$ & ND & ND & FIM \\
\hline Xie et $\mathrm{al}^{44}$ & China & ND & $30 / 30$ & $53.7 \pm 6.1$ & $51.4 \pm 7.2$ & NIHSS, BI \\
\hline Zhao et $\mathrm{al}^{45}$ & China & ND & $18 / 23$ & $53.3 \pm 18.9$ & $50.2 \pm 20.0$ & NIHSS \\
\hline
\end{tabular}

Note: Data are presented as mean \pm SD or median.

Abbreviations: ND, nondetermined; NIHSS, National Institutes of Health Stroke Scale; BI, Barthel index; FMA, Fugl-Meyer Assessment; FIM, Functional Independence Measure; $A E$, adverse event. 
Table 2 Information of MSC therapy

\begin{tabular}{|c|c|c|c|c|c|c|c|}
\hline \multirow{2}{*}{$\begin{array}{l}\text { Included } \\
\text { studies }\end{array}$} & \multicolumn{2}{|c|}{ Therapeutic regimen } & \multirow{2}{*}{$\begin{array}{l}\text { Administration } \\
\text { route }\end{array}$} & \multirow[t]{2}{*}{ Cell dose (cycles) } & \multirow{2}{*}{$\begin{array}{l}\text { Enrollment } \\
\text { period }\end{array}$} & \multirow{2}{*}{$\begin{array}{l}\text { Follow-up } \\
\text { (months) }\end{array}$} & \multirow[t]{2}{*}{ Adverse events } \\
\hline & Experimental & Control & & & & & \\
\hline Bang et $\mathrm{al}^{23}$ & Con Reg+BMSC & $\mathrm{RM}+\mathrm{G}-\mathrm{CSF}$ & IVE & $5 \times 10^{7}$ ( 2 cycles $)$ & ND & 52 & $\begin{array}{l}\text { No obvious adverse } \\
\text { reactions }\end{array}$ \\
\hline Bhasin et $\mathrm{al}^{24}$ & Con Reg+BMSC & RM & IVE & $5-6 \times 10^{7}$ (I cycle $)$ & ND & 6 & $\begin{array}{l}\text { No obvious adverse } \\
\text { reactions }\end{array}$ \\
\hline Bhasin et $\mathrm{al}^{25}$ & Con Reg+BMSC & RM & IVE & $5-6 \times 10^{7}$ (I cycle) & ND & 6 & Fever (I); pain (2) \\
\hline Cai et a $\mathrm{a}^{26}$ & Con Reg+BMSC & RM & IVE & $0.5-2 \times 10^{8}$ ( 3 cycles $)$ & $20|4|-.20|5|$. & 6 & ND \\
\hline Cheng et $\mathrm{al}^{27}$ & Con Reg+BMSC & RM & IVE & $0.5-2 \times 10^{8}$ ( 3 cycles $)$ & $2011.1-2012.12$ & 3 & ND \\
\hline Chen et $\mathrm{al}^{28}$ & Con Reg+BMSC & RM & SUB & $\mathrm{I} \times 10^{6} / \mathrm{kg}(\mathrm{I}$ cycle $)$ & $2009.12-2011.8$ & 5 & ND \\
\hline Chen et $\mathrm{a}^{29}$ & Con Reg+BMSC & RM & SUB & $3-5 \times 10^{6}$ ( 2 cycles $)$ & $2009.1-2011.5$ & 6 & $\begin{array}{l}\text { Low-grade fever } \\
\text { (3); headache (4) }\end{array}$ \\
\hline Deng et $\mathrm{al}^{30}$ & Con Reg+BMSC & $\mathrm{RM}+\mathrm{SM}$ & IVE & $1-5 \times 10^{7}$ ( 3 cycles $)$ & ND & 1 & $\begin{array}{l}\text { No obvious adverse } \\
\text { reactions }\end{array}$ \\
\hline Feng et $\mathrm{al}^{31}$ & Con Reg+UBMSC & RM & IT, IVE & $3 \times 10^{7}$ (6 cycles) & $2010.9-2013.2$ & 3 & Low-grade fever (I) \\
\hline $\mathrm{He}^{32}$ & Con Reg+BMSC & RM & IVE & $1 \times 10^{8}(\mathrm{I}$ cycle $)$ & $2010.4-2012.2$ & 3 & ND \\
\hline Hu et a ${ }^{33}$ & Con Reg+UCMSC & RM & IT+IVE & $1 \times 10^{8}(\mathrm{I}$ cycle $)$ & $2011.4-2012.6$ & 3 & $\begin{array}{l}\text { Low-grade fever } \\
(12) \text {; headache }(5) \text {; } \\
\text { flank soreness (I0) }\end{array}$ \\
\hline $\mathrm{Ji}$ et $\mathrm{a}^{34}$ & Con Reg+UCMSC & RM & IVE & $1 \times 10^{7}(\mid$ cycle $)$ & $2009-2010$ & 6 & $\begin{array}{l}\text { No obvious adverse } \\
\text { reactions }\end{array}$ \\
\hline Lee et $\mathrm{a}^{35}$ & Con Reg+BMSC & RM & IVE & $5 \times 10^{7}$ ( 2 cycles $)$ & $2003.7-2005.12$ & 60 & $\begin{array}{l}\text { No obvious adverse } \\
\text { reactions }\end{array}$ \\
\hline Liu et $\mathrm{al}^{36}$ & Con Reg+BMSC & RM & SUB & $\mathrm{I} \times 10^{7} / \mathrm{kg}$ (4 cycles) & $2010.12-2012.12$ & 3 & $\begin{array}{l}\text { No obvious adverse } \\
\text { reactions }\end{array}$ \\
\hline Meng et $\mathrm{al}^{37}$ & Con Reg+BMSC & RM & IVE & $2.97 \times 10^{9}(1$ cycle $)$ & 2003.6-2008.6 & 6 & $\begin{array}{l}\text { Low-grade fever } \\
\text { (4); headache (3) }\end{array}$ \\
\hline Shen ${ }^{38}$ & Con Reg+UCMSC & RM & IC & ND & $2012.1-2013.12$ & 3 & ND \\
\hline Song et $\mathrm{al}^{39}$ & Con Reg+UBMSC & $\mathrm{RM}$ & IT+IVE & ND & 2009-2010 & 1 & Low-grade fever (5) \\
\hline Sun et $\mathrm{al}^{40}$ & $\begin{array}{l}\text { Con Reg+BMSC } \\
+ \text { G-CSF }\end{array}$ & RM & IVE & $1.4 \pm 0.6 \times 10^{8}(\mathrm{I}$ cycle $)$ & $2006.8-2007.6$ & 3 & ND \\
\hline Sun et $\mathrm{al}^{41}$ & Con Reg+BMSC & RM & IVE & ND (3 cycles) & $20|I .8-20| 2.8$ & 3 & Low-grade fever (2) \\
\hline Tsang et a $\mathrm{a}^{142}$ & Con Reg+BMSC & RM & IVE & $4.57 \times 10^{7}(1$ cycle $)$ & ND & 15 & $\begin{array}{l}\text { No obvious adverse } \\
\text { reactions }\end{array}$ \\
\hline Wang et a ${ }^{43}$ & Con Reg+BMSC & RM & ND & $\mathrm{I}-2 \times 10^{8}(\mathrm{I}$ cycle $)$ & $2009.1-2010.6$ & 6 & $\begin{array}{l}\text { No obvious adverse } \\
\text { reactions }\end{array}$ \\
\hline Xie et $\mathrm{al}^{44}$ & Con Reg+BMSC & RM & SUB & $2 \times 10^{7}$ (I cycle $)$ & $2011.1-2012.7$ & 6 & $\begin{array}{l}\text { Low-grade fever } \\
\text { (3); headache (4) }\end{array}$ \\
\hline Zhao et al ${ }^{45}$ & Con Reg+BMSC & RM & SUB & ND & ND & I & Fever (I) \\
\hline
\end{tabular}

Abbreviations: Con Reg, control group regimen; RM, routine medication; MSC, mesenchymal stem cell; BMSC, bone marrow mesenchymal stem cell; UBMSC, umbilical cord blood mesenchymal stem cell; UCMSC, umbilical cord mesenchymal stem cell; ND, nondetermined; SM, Salvia miltiorrhiza; G-CSF, granulocyte colony-stimulating factor; IVE, intravenous; IT, intrathecal; SUB, subarachnoid; IC, intracarotid.

third and sixth month after treatment ( 1 month: $\mathrm{OR}=-5.20$, $\mathrm{CI}=-6.52$ to $-3.87, P<0.00001 ; 2$ months: $\mathrm{OR}=-6.46$, $\mathrm{CI}=-7.86$ to $-5.06, P<0.00001 ; 3$ months: $\mathrm{OR}=-7.50$, $\mathrm{CI}=-9.59$ to $-5.40, P<0.00001 ; 6$ months: $\mathrm{OR}=-9.19$, $\mathrm{CI}=-11.77$ to $-6.60, P<0.00001$; Figure $\mathrm{S} 1)$. As shown in Figure 3, compared to the control group, the NIHSS score of the experimental group was lower in the first $(\mathrm{OR}=-1.92$, $\mathrm{CI}=-3.49$ to $-0.34, P=0.02)$ and third month $(\mathrm{OR}=-2.65$, $\mathrm{CI}=-3.40$ to $-1.90, P<0.00001)$.

\section{Effectiveness of MSCs assessed by the BI score}

The postoperative BI score was increased after combined therapy in the first, second, third and sixth month and after 12 months ( 1 month: $\mathrm{OR}=30.14, \mathrm{CI}=29.34-30.94$, $P<0.00001 ; 2$ months: $\mathrm{OR}=15.50, \mathrm{CI}=2.99-28.01, P=0.02 ; 3$ months: $\mathrm{OR}=29.66, \mathrm{CI}=24.12-35.20, P<0.00001 ; 6$ months: $\mathrm{OR}=27.76, \mathrm{CI}=13.24-42.28, P=0.0002$; after 1 year: $\mathrm{OR}=45.79$, $\mathrm{CI}=37.32-54.25, P<0.00001$; Figure S2). In the comparison between patients treated by combined therapy and RT alone, the $\mathrm{BI}$ score in the combined therapy group was higher in the first and sixth month ( 1 month: $\mathrm{OR}=0.99, \mathrm{CI}=0.19-1.79, P=0.02 ; 6$ months: $\mathrm{OR}=10.10, \mathrm{CI}=3.07-17.14, P=0.005$; Figure 4).

\section{Effectiveness of MSCs assessed by the FMA score}

The FMA score after combined therapy was significantly increased in the first, second, third and sixth month, and 
A

B

\begin{tabular}{|c|c|c|c|c|c|c|c|}
\hline & 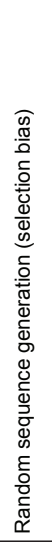 & 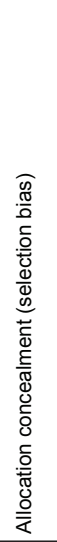 & 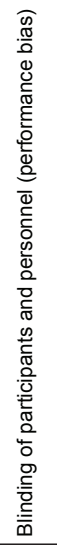 & 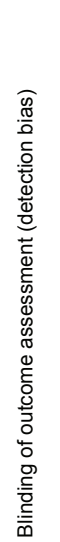 & 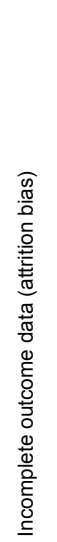 & 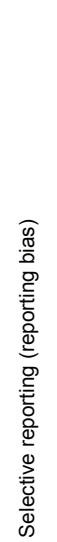 & 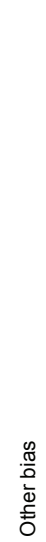 \\
\hline Bang et $\mathrm{al}^{23}$ & + & + & + & + & + & + & $?$ \\
\hline Bhasin et a ${ }^{24}$ & $\theta$ & $?$ & $\theta$ & + & O & + & + \\
\hline Bhasin et a $\left.\right|^{25}$ & $\theta$ & $?$ & $\theta$ & + & O & + & + \\
\hline Cai et al $1^{26}$ & + & + & + & + & + & + & $?$ \\
\hline Cheng et $\mathrm{al}^{27}$ & $?$ & $?$ & $?$ & + & + & + & $?$ \\
\hline Chen et al ${ }^{28}$ & + & + & + & + & + & + & $?$ \\
\hline Chen et $\mathrm{a}^{29}$ & $\theta$ & \begin{tabular}{|l|}
$?$ \\
\end{tabular} & $\theta$ & + & + & + & $?$ \\
\hline Deng et $a^{30}$ & $?$ & $?$ & $?$ & + & + & + & $?$ \\
\hline Feng et $\mathrm{al}^{31}$ & + & + & + & + & + & + & + \\
\hline $\mathrm{He}^{32}$ & + & + & + & + & + & + & $?$ \\
\hline Hu et al $\mathbf{l}^{33}$ & + & + & + & + & + & + & + \\
\hline Ji et a $\left.\right|^{34}$ & + & + & + & + & + & + & $?$ \\
\hline Lee et $\mathbf{a}^{35}$ & + & + & + & + & + & + & + \\
\hline Liu et a $\mathbf{a}^{36}$ & + & + & + & + & + & + & $?$ \\
\hline Meng et $\mathrm{a}^{37}$ & $\oplus$ & + & + & + & + & + & $?$ \\
\hline Shen $^{38}$ & + & + & + & + & + & + & $?$ \\
\hline Song et a $\left.\right|^{39}$ & $\theta$ & $?$ & $\theta$ & + & + & + & $?$ \\
\hline Sun et $\mathbf{a}^{40}$ & + & + & + & + & + & + & $?$ \\
\hline Sun et al ${ }^{41}$ & + & + & + & + & + & + & + \\
\hline Tsang et al $\mathrm{a}^{42}$ & + & + & + & + & $\theta$ & $?$ & + \\
\hline Wang et al ${ }^{43}$ & + & + & + & + & + & + & $?$ \\
\hline Xie et $\mathbf{a}^{\mid 44}$ & + & + & + & + & + & + & + \\
\hline Zhao et al ${ }^{45}$ & $\theta$ & $?$ & $\theta$ & + & + & + & $?$ \\
\hline
\end{tabular}

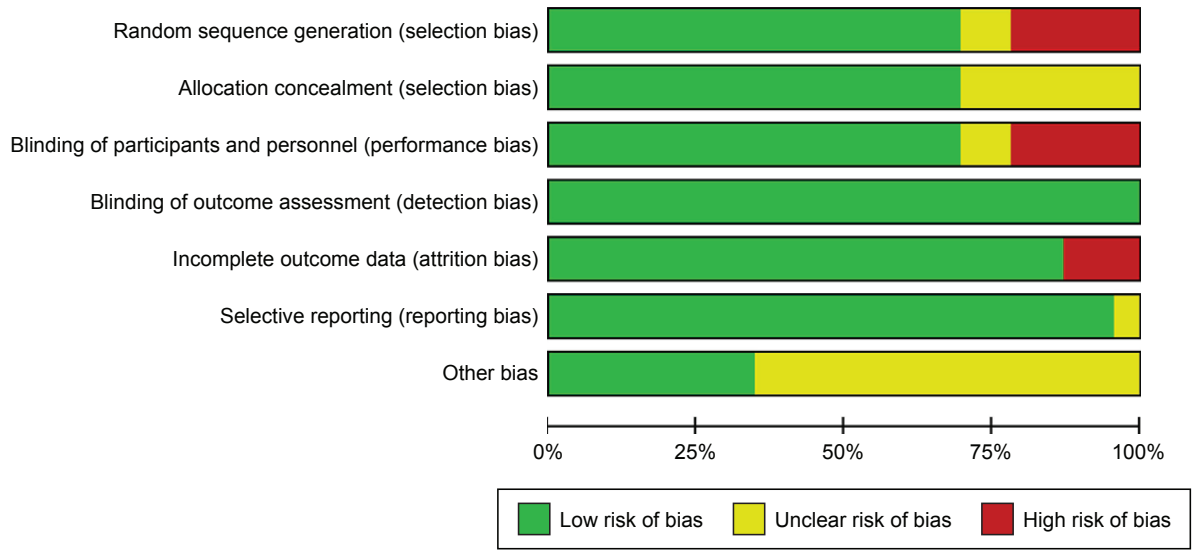

Figure 2 (A) Risk-of-bias summary: review of authors' judgments about each risk-of-bias item for included studies. (B) Risk-of-bias graph: review of authors' judgments about each risk-of-bias item presented as percentages across all included studies.

Note: Each color represents a different level of bias. 


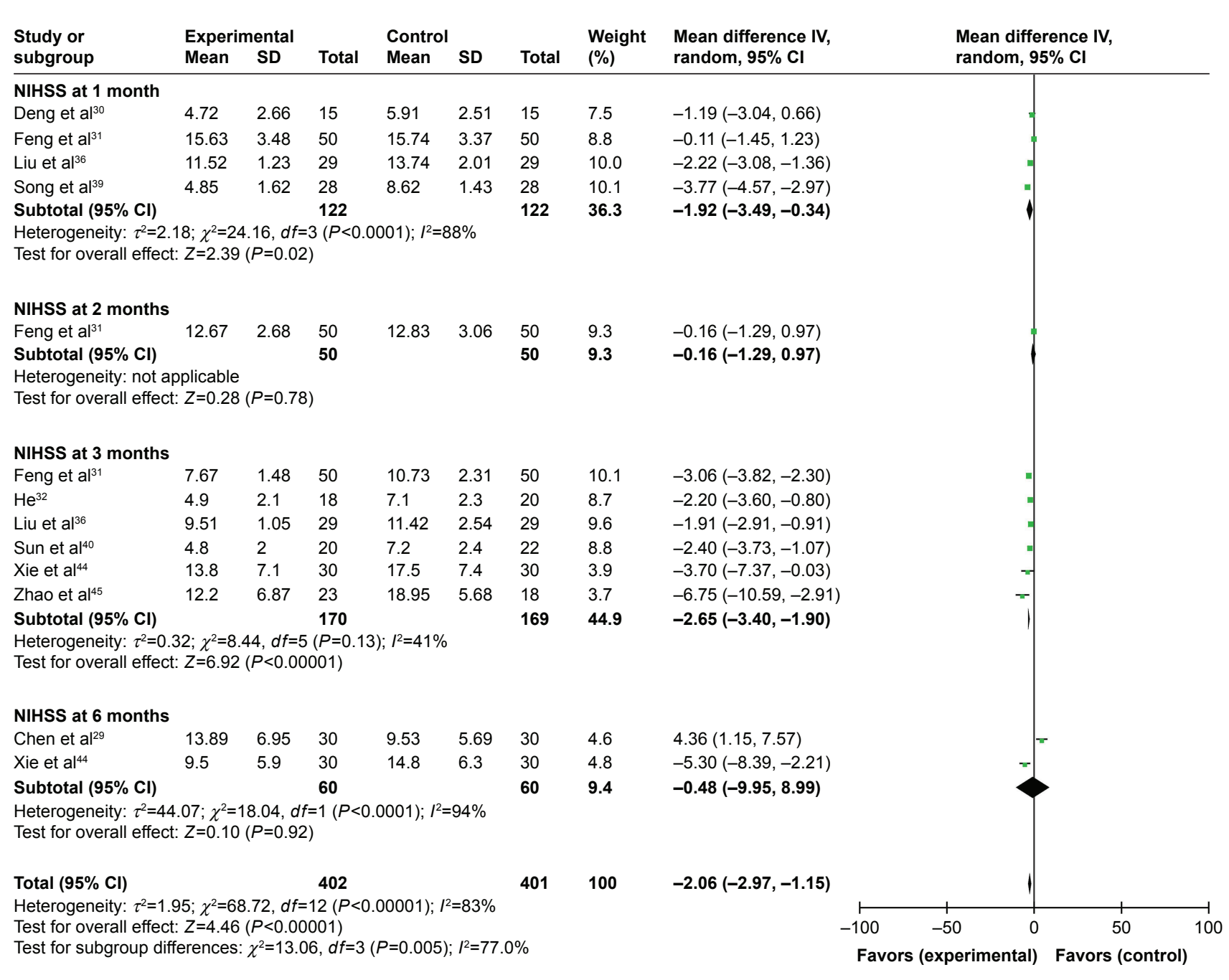

Figure 3 Forest plot of the comparison of NIHSS scores between the experimental and control groups.

Notes: Control group, RT alone group; experimental group, RT plus MSC therapy. The random-effects meta-analysis model (inverse variance method) was used.

Abbreviations: IV, inverse variance; NIHSS, National Institutes of Health Stroke Scale; RT, routine treatment; MSC, mesenchymal stem cell.

after 12 months ( 1 month: $\mathrm{OR}=15.49, \mathrm{CI}=7.51-23.47$, $P=0.0001 ; 2$ months: $\mathrm{OR}=18.46, \mathrm{CI}=7.11-29.82, P=0.001$; 3 months: $\mathrm{OR}=27.00, \mathrm{CI}=19.78-34.23, P<0.00001$; 6 months: $\mathrm{OR}=39.26, \mathrm{CI}=25.85-52.67, P<0.00001$; after 1 year: $\mathrm{OR}=36.40, \mathrm{CI}=29.31-43.49, P<0.00001$; Figure $\mathrm{S} 3$ ). A comparison between the two groups indicated a significantly increased FMA score in the third and sixth month postoperation in the combined therapy group (3 months: $\mathrm{OR}=10.20, \mathrm{CI}=3.70-16.70, P=0.002 ; 6$ months: $\mathrm{OR}=10.82$, $\mathrm{CI}=6.45-15.18, P<0.00001$; Figure 5).

\section{Effectiveness of MSCs assessed by the FIM score}

As shown in Figure 3, the FIM score was increased after combined therapy, especially in the first, third and sixth month postoperation $(1$ month: $\mathrm{OR}=24.47, \mathrm{CI}=7.14-41.80$, $P=0.006 ; 3$ months: $\mathrm{OR}=24.05, \mathrm{CI}=6.56-41.54, P=0.007$;
6 months: $\mathrm{OR}=48.13, \mathrm{CI}=32.04-64.23, P<0.00001$; Figure S4). Meanwhile, the FIM score in the combined therapy group was higher than that of the control group in the first and sixth month ( 1 month: $\mathrm{OR}=15.61, \mathrm{CI}=-0.02$ to $31.24, P=0.05 ; 6$ months: $\mathrm{OR}=16.56, \mathrm{CI}=9.06-24.06$, $P<0.0001$; Figure 6).

\section{Adverse event assessment}

We evaluated the safety of MSC therapy in this metaanalysis. The most common side effects of MSC treatment were headache and fever, which usually subsided within 24 hours without treatment. No serious adverse events were reported in the involved studies (Table 1). However, the incidence of side effects in experimental and control groups was not compared in most included trials. Three studies ${ }^{25,35,42}$ conducted the comparison of adverse events including 


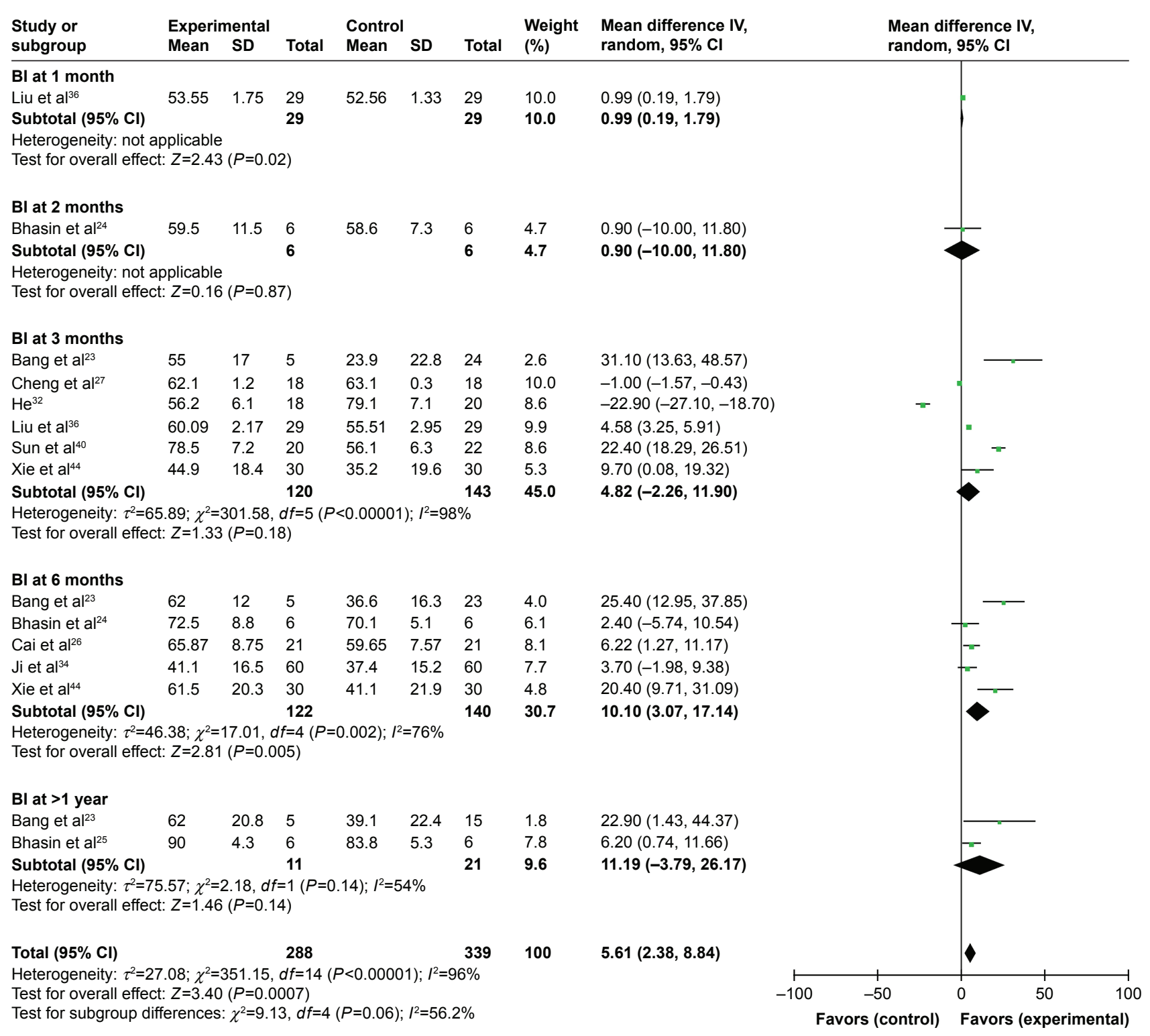

Figure 4 Forest plot of the comparison of the Bl scores between the experimental and control groups.

Notes: Control group, RT alone group; experimental group, RT plus MSC therapy. The random-effects meta-analysis model (inverse variance method) was used. Abbreviations: IV, inverse variance; BI, Barthel index; RT, routine treatment; MSC, mesenchymal stem cell.

infection, tumor formation, seizures, psychological illness, death and fever. Except death, no significant difference was found for other indicators between the two groups (infection: $\mathrm{OR}=0.69, \mathrm{CI}=0.16-2.99, P=0.62$; tumor formation: $\mathrm{OR}=0.72$, $\mathrm{CI}=0.03-18.56, P=0.84$; seizures: $\mathrm{OR}=1.02, \mathrm{CI}=0.26-3.93$, $P=0.98$; psychological illness: $\mathrm{OR}=1.69, \mathrm{CI}=0.53$ 5.33, $P=0.37$; death: $\mathrm{OR}=0.24, \mathrm{CI}=0.06-0.88, P=0.03$; fever: $\mathrm{OR}=5.03, \mathrm{CI}=0.48-52.71, P=0.18$; Figure 7 ).

\section{Publication bias}

Based on the NIHSS, ${ }^{31,32,36,40,44,45} \mathrm{BI},{ }^{23,24,26,27,32,34,36,40,42,44}$ FMA $^{28,31,33,36,37,41}$ and FIM $^{27,28,33,37,38,42}$ data, funnel plots were drawn for the studies. The funnel plots were symmetrical, indicating no existence of publication bias (Figures 8 and S5).

\section{Sensitivity analysis}

To further evaluate the effects of clinical variables including cell types and different administration routes on clinical efficacy of patients with different characteristics, we performed subgroup analysis. Results showed that MSC therapy was more effective when infusion was performed through vein, and autogenous MSCs were superior to those derived from other sources, indicated by increased BI, FMA and FIM scores (Table 3). 


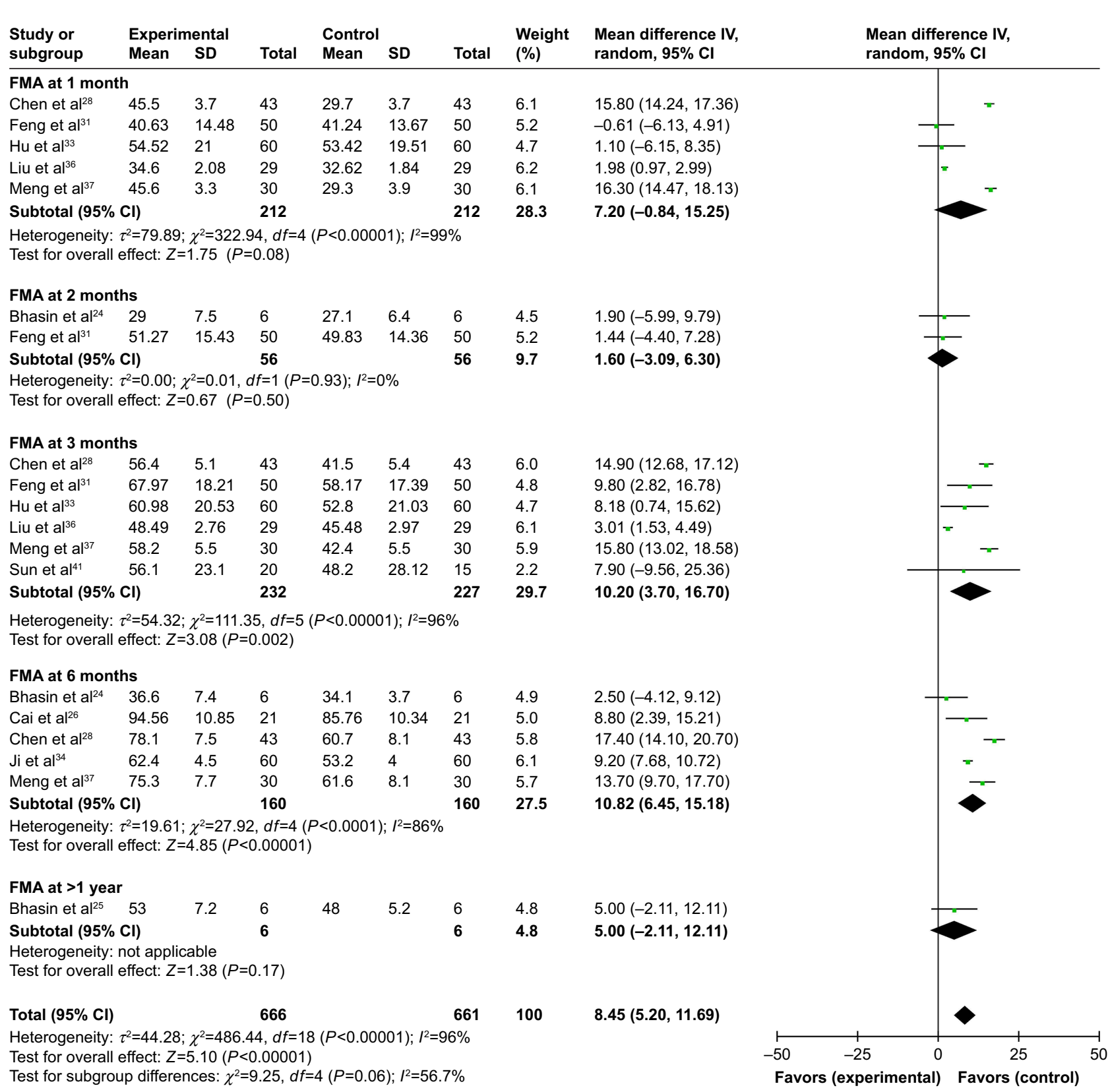

Figure 5 Forest plot of the comparison of FMA scores between the experimental and control groups.

Notes: Control group, RT alone group; experimental group, RT plus MSC therapy. The random-effects meta-analysis model (inverse variance method) was used.

Abbreviations: IV, inverse variance; FMA, Fugl-Meyer Assessment; RT, routine treatment; MSC, mesenchymal stem cell.

\section{Discussion}

MSC transfusion has been considered as a promising option to treat IS due to its unique biological characteristics. Transfused MSCs can migrate to infarction area and induce angiogenesis, ${ }^{46,47}$ reduce neuron apoptosis, ${ }^{48,49}$ enhance axonal regeneration and rebuild synapses. Upon stimulating the release of cytokines and neurotrophic factors, ${ }^{3,50}$ such as brain-derived neurotrophic factor, ${ }^{3}$ basic fibroblast growth factor $^{15}$ and vascular endothelial growth factor, ${ }^{3,51}$ MSCs also promote the differentiation of endogenous neural stem and progenitor cells. Most importantly, the low immunogenicity of MSCs reduces the possibility of graft-versus-host reaction. ${ }^{1,15}$

In recent years, several studies reported that MSC therapy is a safe and feasible treatment option for IS, ${ }^{23-45}$ but different clinical protocols among studies may bring different therapeutic effects. In this study, we performed an extensive and systematic analysis of published clinical trials to assure statistical reliability. Our meta-analysis revealed that compared to IS patients treated by RT alone, those treated by 


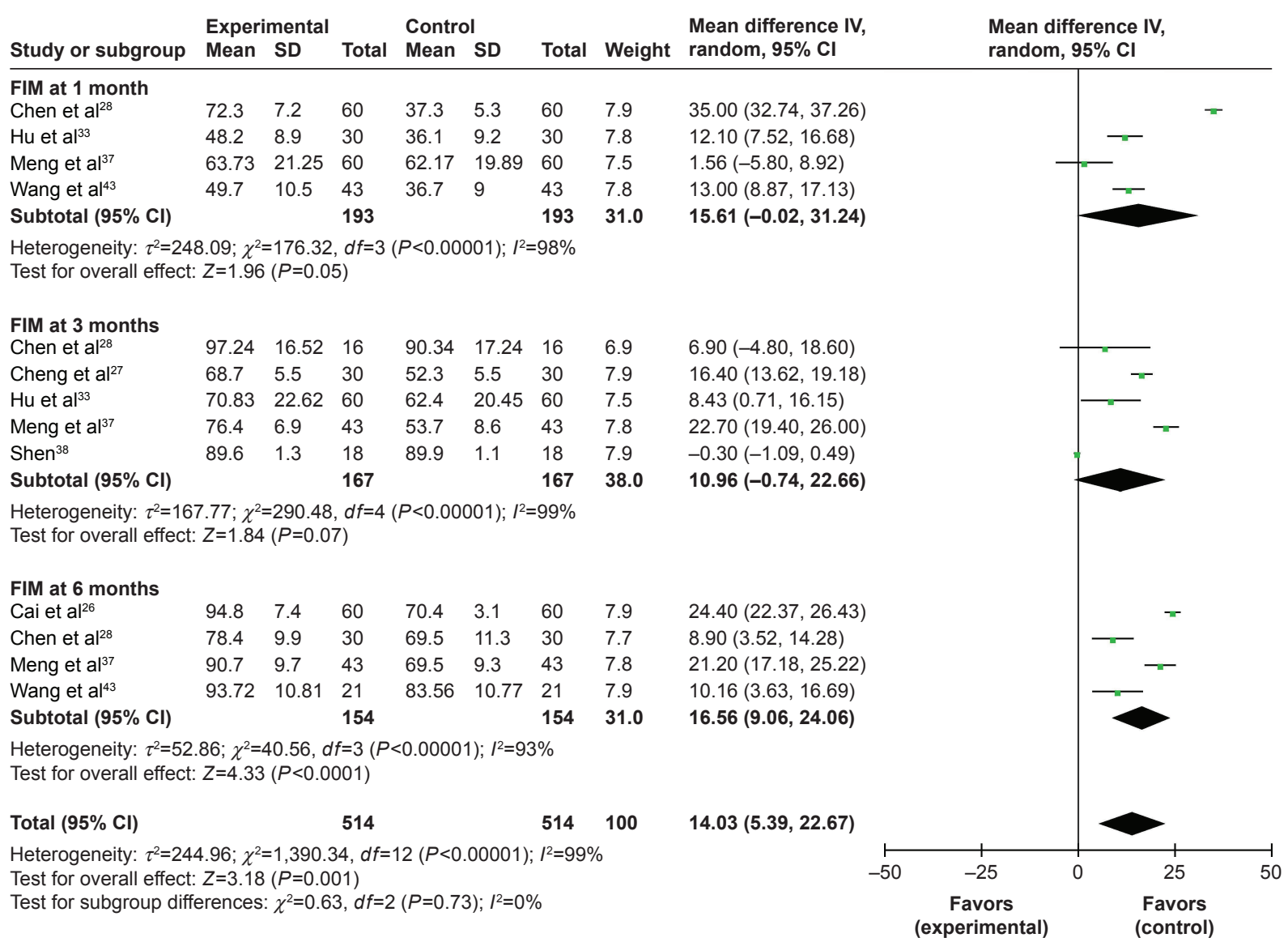

Figure 6 Forest plot of the comparison of the FIM scores between the experimental and control groups.

Notes: Control group, RT alone group; experimental group, RT plus MSC therapy. The random-effects meta-analysis model (inverse variance method) was used. Abbreviations: IV, inverse variance; FIM, Functional Independence Measure; RT, routine treatment; MSC, mesenchymal stem cell.

MSC and RT combined therapy exhibited more favorable therapeutic efficacy, indicated by decreased NIHSS and increased BI, FMA and FIM scores.

MSC therapy has been applied to treat refractory diseases for years with satisfied safety record, ${ }^{52-55}$ and our analysis showed that MSCs were safe in treating IS as well. No serious adverse events have been reported during MSC therapy. Most common side effects, including fever and headache, usually resolved naturally. However, relevant studies were insufficient, and the potential long-term toxicity and the risk of tumor formation are unknown, which usually take years to occur. More research evidence will be required to support the safety of combined therapy.

Therapeutic effects of MSC therapy may be affected by infusion routes, cell dosages, cell types and patients' characteristics. We found that intravenous infusion is generally superior to subarachnoid injection in therapeutic effects, but there were also contradicted conclusions drawn from different researches. There are articles that claimed that local subarachnoid injection may deliver a larger number of transplanted MSCs to the stroke lesion thereby promoting nerve recovery and regeneration. ${ }^{2,56}$ However, the different routes of cell infusion did not make big difference in other researches, ${ }^{57}$ which speculated that MSCs treat IS through releasing growth factors and antiapoptotic factors instead of homing to the nerve system. ${ }^{3,58}$ The treatment effect varies at different time points of detection, and dosages of transfused MSCs are a key factor in therapeutic strategy optimization. There are studies that showed that increased number of infused cells contributed to favorable clinical efficacy, ${ }^{57}$ but currently published literature is still not sufficient to perform reliable statistical analysis. Sources of MSC may also associate with treatment outcomes. Based on our extracted data, autogenous MSCs were associated with increased BI and FIM score, indicating a better therapeutic effect than allogenic MSCs for IS. However, our data were not sufficient, and more research evidence is needed to support this conclusion. The optimal conduction time of cell delivery is also undetermined 


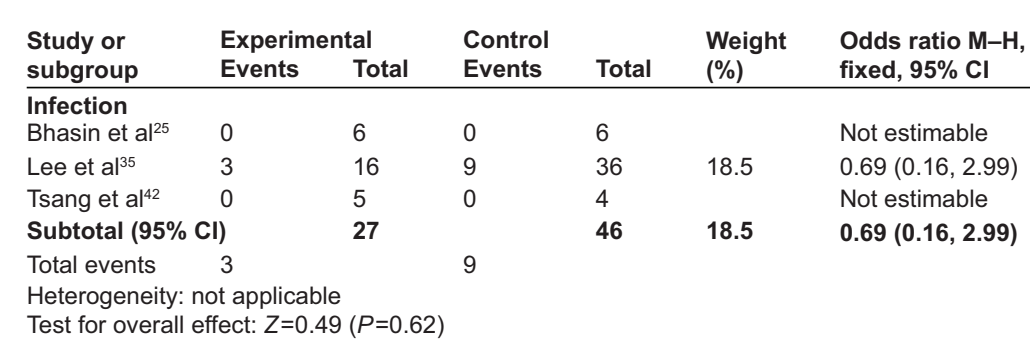

\section{Tumor formation}

Bhasin et $\mathrm{al}^{25} \quad 0$

Lee et $\mathrm{al}^{35} \quad 0$

Tsang et $\mathrm{al}^{42} \quad 0$

Subtotal $(95 \% \mathrm{CI})$

Total events 0

Heterogeneity: not applicable

Test for overall effect: $Z=0.20(P=0.84)$

\section{Seizures}

Bhasin et $\mathrm{al}^{25}$

Lee et $\mathrm{al}^{35} \quad 3$

Subtotal $(95 \% \mathrm{CI})$

Total events 4

Heterogeneity: $\chi^{2}=0.63, d f=1(P=0.43) ; l^{2}=0 \%$

Test for overall effect: $Z=0.03(P=0.98)$

\section{Psychological illness}

Bhasin et $\mathrm{al}^{25} 1$

Lee et $\mathrm{al}^{35} \quad 6$

Subtotal $(95 \% \mathrm{Cl})$

Total events $\quad 7$

Heterogeneity: $\chi^{2}=1.40, d f=1(P=0.24) ; I^{2}=29 \%$

Test for overall effect: $Z=0.89(P=0.37)$

Death

Bhasin et $\mathrm{al}^{25}$

Bhasin et $\mathrm{al}^{25} \quad 0$

Lee et $\mathrm{al}^{35}$

Subtotal $(95 \% \mathrm{CI})$

Total events 4

$6 \quad 0$

$16 \quad 21$

22

Heterogeneity: not applicable

Test for overall effect: $Z=2.14(P=0.03)$

\section{Fever}

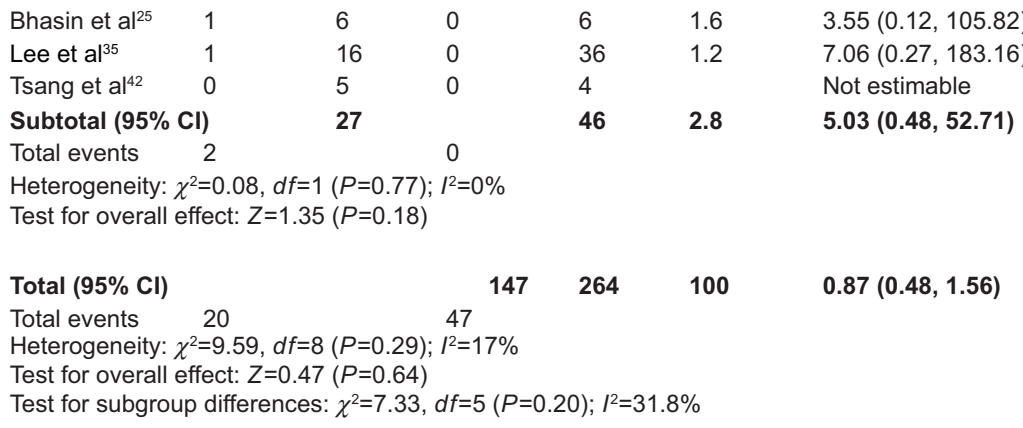

Not estimable

$0.72(0.03,18.56)$

Not estimable

$0.72(0.03,18.56)$
$0.40(0.03,6.18)$

$1.43(0.30,6.88)$

$1.02(0.26,3.93)$

$0.40(0.03,6.18)$

$2.49(0.67,9.18)$

$1.69(0.53,5.33)$

Not estimable

$0.24(0.06,0.88)$

$0.24(0.06,0.88)$

39.9

$0.24(0.06,0.88)$
Odds ratio $\mathrm{M}-\mathrm{H}$,

fixed, $95 \% \mathrm{Cl}$

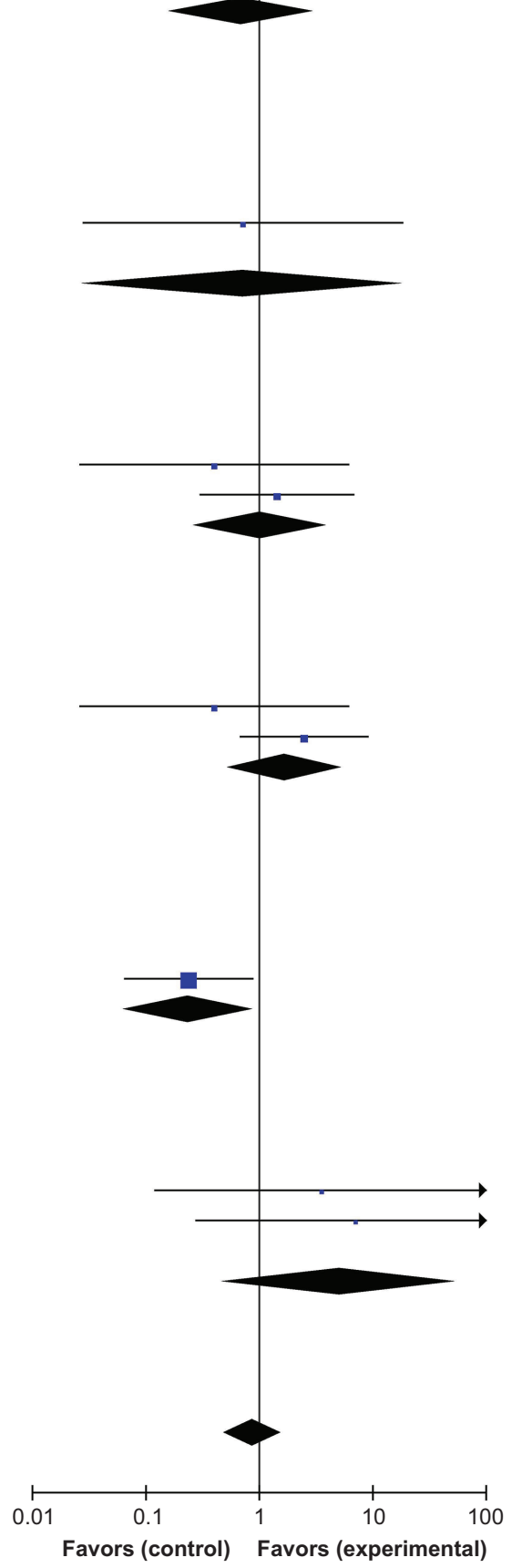

Figure 7 Forest plot of the comparison of adverse events between the experimental and control groups.

Notes: Control group, RT alone group; experimental group, RT plus MSC therapy. The fixed-effects meta-analysis model (Mantel-Haenszel method) was used. Abbreviations: M-H, Mantel-Haenszel; RT, routine treatment; MSC, mesenchymal stem cell.

yet. Preclinical studies showed that early intervention leads to an obvious relief of neurological defects. ${ }^{2,59}$ Our subgroup analysis suggested no significant difference in outcomes between the acute and chronic phases of stroke.

\section{Limitations}

There are some limitations in this analysis. First of all, the numbers of involved studies and patients were small and the follow-up period was short, which may cause publication 

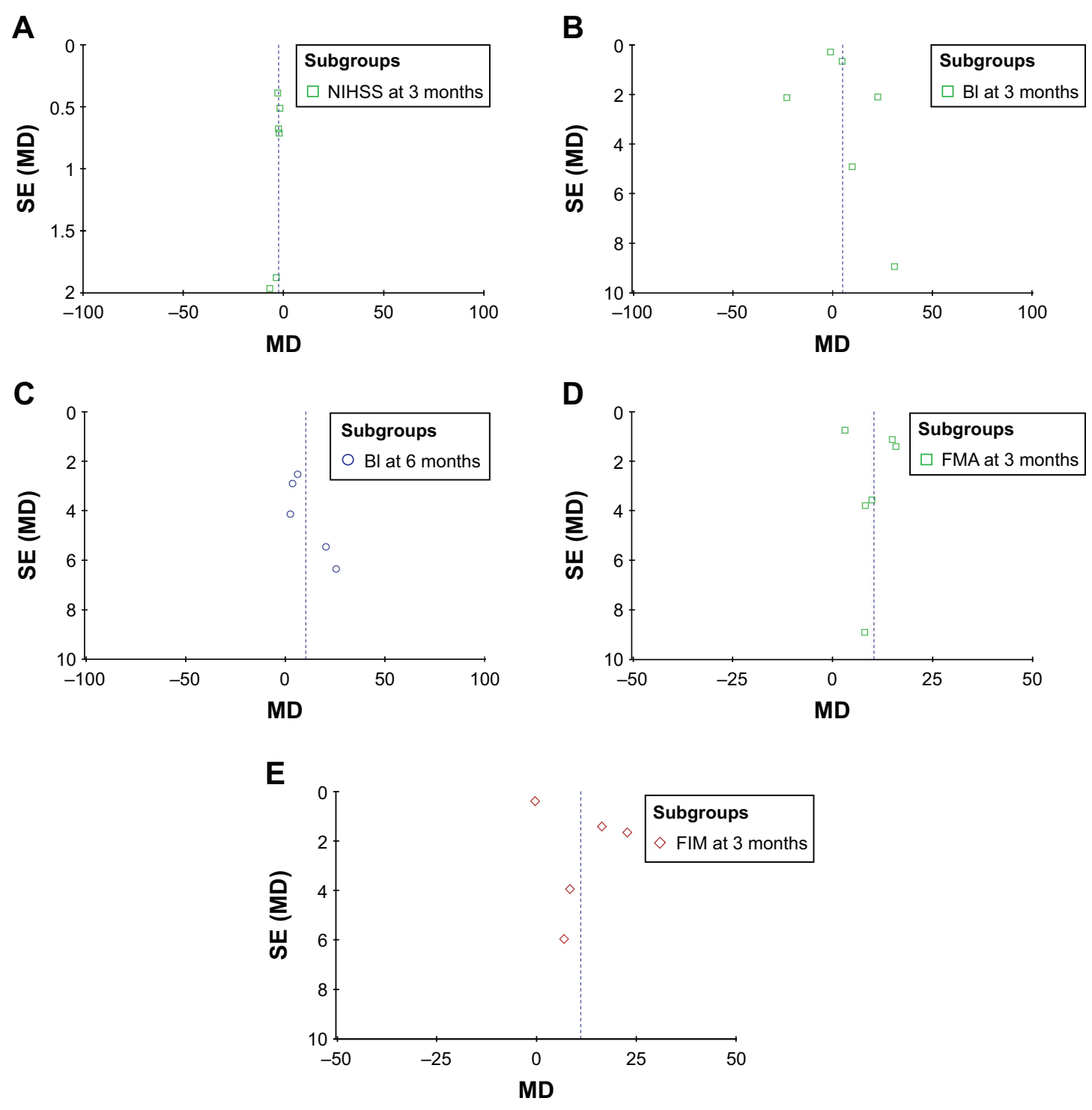

Figure 8 Funnel plot of the NIHSS (A), BI (B and C), FMA (D) and FIM (E) scores between the experimental and control groups. Note: Parameters were discussed in over five studies which were included in bias analyses.

Abbreviations: SE, standard error; MD, mean difference; NIHSS, National Institutes of Health Stroke Scale; BI, Barthel index; FMA, Fugl-Meyer Assessment; FIM, Functional Independence Measure.

bias. Second, all trials included in this paper were mainly conducted in Asian countries. There were indeed several trials conducted in non-Asian countries included upon the first retrieve. However, no paper meeting our inclusion criteria has been produced based on these trials, and studies were excluded due to insufficient data, and being case reports, unrelated to MSC therapy or without control group. We will keep paying close attention to global studies in this field and carry out further analyses in our later studies. Third, our data were partly extracted from published papers rather than original patient records, which means we were not able to avoid the analytical bias based on the information presented in them. In addition, different trials evaluated the treatment efficacy by different outcomes, which have to be summarized using various scales when assessed in this study, leading to small sample sizes in each statistical analysis. Due to above limitations, future studies and generated data will be valuable to further verify the safety and efficacy of MSC therapy.

\section{Conclusion}

In summary, our analysis verified the safety and efficacy of MSC therapy for IS. It significantly mitigated neurological defects and improved life quality of IS patients, without causing serious adverse events. Therefore, MSC therapy is a promising treatment option for IS patients. 
Table 3 Subgroup analyses of NIHSS, BI, FMA and FIM between the experimental and control groups

\begin{tabular}{|c|c|c|c|c|c|c|c|c|c|}
\hline \multirow{2}{*}{$\begin{array}{l}\text { Parameter (TP } \\
\text { after surgery) }\end{array}$} & \multirow[t]{2}{*}{ Factors at study level } & \multirow{2}{*}{$\begin{array}{l}\text { Experimental } \\
\text { group } \\
\text { No. of } \\
\text { patients }(\mathrm{n})\end{array}$} & \multirow{2}{*}{$\begin{array}{l}\begin{array}{l}\text { Control } \\
\text { group }\end{array} \\
\begin{array}{l}\text { No. of } \\
\text { patients (n) }\end{array}\end{array}$} & \multirow{2}{*}{$\begin{array}{l}\text { Analysis } \\
\text { method }\end{array}$} & \multicolumn{2}{|c|}{ Heterogeneity } & \multirow[t]{2}{*}{ OR } & \multirow[t]{2}{*}{$95 \% \mathrm{Cl}$} & \multirow[t]{2}{*}{$P$-value } \\
\hline & & & & & $P^{2}(\%)$ & $P$-value & & & \\
\hline \multirow[t]{6}{*}{ NIHSS (Month 3) } & Cell type & & & & & & & & \\
\hline & Auto-MSC & 120 & 119 & Random & 37 & 0.18 & -2.49 & -3.45 to -1.54 & $<0.0000$ I \\
\hline & Allo-MSC & 50 & 50 & Random & & & -3.06 & -3.82 to -2.30 & $<0.0000 \mathrm{I}$ \\
\hline & Route of delivery & & & & & & & & \\
\hline & Subarachnoid & 82 & 77 & Random & 68 & 0.04 & -3.66 & -6.53 to -0.80 & 0.01 \\
\hline & Intravenous & 38 & 42 & Random & 0 & 0.84 & -2.30 & -3.27 to -1.34 & $<0.00001$ \\
\hline \multirow[t]{3}{*}{ BI (Month 3) } & Route of delivery & & & & & & & & \\
\hline & Subarachnoid & 59 & 59 & Random & 6 & 0.30 & 4.83 & $2.66-7.0 \mathrm{I}$ & $<0.0001$ \\
\hline & Intravenous & 61 & 84 & Random & 99 & $<0.00001$ & 6.02 & -10.58 to 22.63 & 0.48 \\
\hline \multirow[t]{9}{*}{ BI (Month 6) } & Cell type & & & & & & & & \\
\hline & Auto-MSC & 62 & 80 & Random & 80 & 0.002 & 12.48 & $3.01-21.94$ & 0.010 \\
\hline & Allo-MSC & 60 & 60 & Random & & & 3.70 & -1.98 to 9.38 & 0.20 \\
\hline & Route of delivery & & & & & & & & \\
\hline & Subarachnoid & 30 & 30 & Random & & & 20.40 & $9.7 I-31.09$ & 0.0002 \\
\hline & Intravenous & 92 & 110 & Random & 72 & 0.01 & 7.70 & $0.96-14.44$ & 0.03 \\
\hline & Patients' characteristic & & & & & & & & \\
\hline & Acute stroke & 5 & 23 & Random & & & 25.40 & $12.95-37.85$ & $<0.0001$ \\
\hline & Chronic stroke & 27 & 27 & Random & 0 & 0.43 & 5.19 & $0.96-9.42$ & 0.02 \\
\hline \multirow[t]{6}{*}{ FMA (Month 3) } & Cell type & & & & & & & & \\
\hline & Auto-MSC & 122 & 117 & Random & 97 & $<0.00001$ & 10.76 & $2.38-19.14$ & 0.01 \\
\hline & Allo-MSC & 110 & 110 & Random & 0 & 0.76 & 9.04 & $3.95-14.13$ & 0.0005 \\
\hline & Route of delivery & & & & & & & & \\
\hline & Subarachnoid & 72 & 72 & Random & 99 & $<0.00001$ & 8.92 & -2.73 to 20.58 & 0.13 \\
\hline & Intravenous & 50 & 45 & Random & 0 & 0.38 & 15.60 & $12.86-18.35$ & $<0.00001$ \\
\hline \multirow[t]{6}{*}{ FIM (Month 3) } & Cell type & & & & & & & & \\
\hline & Auto-MSC & 89 & 89 & Random & 84 & 0.002 & 17.28 & $11.01-23.55$ & $<0.00001$ \\
\hline & Allo-MSC & 78 & 78 & Random & 79 & 0.03 & 3.19 & -5.19 to 11.57 & 0.46 \\
\hline & Route of delivery & & & & & & & & \\
\hline & Subarachnoid & 16 & 16 & Random & & & 6.90 & -4.80 to 18.60 & 0.25 \\
\hline & Intravenous & 73 & 73 & Random & 88 & 0.004 & 19.49 & $|3.3|-25.66$ & $<0.0000$ I \\
\hline
\end{tabular}

Abbreviations: TP, time point; OR, odds ratio; NIHSS, National Institutes of Health Stroke Scale; BI, Barthel index; FMA, Fugl-Meyer Assessment; FIM, Functional Independence Measure; auto-MSC, autogenous mesenchymal stem cell; allo-MSC, allogenic mesenchymal stem cell.

\section{Author contributions}

All authors contributed toward data analysis, drafting and critically revising the paper and agree to be accountable for all aspects of the work.

\section{Disclosure}

The authors report no conflicts of interest in this work.

\section{References}

1. Chen L, Zhang G, Khan AA, Guo X, Gu Y. Clinical efficacy and metaanalysis of stem cell therapies for patients with brain ischemia. Stem Cells Int. 2016;2016:6129579.

2. Kumar A, Prasad M, Jali VP, et al. Bone marrow mononuclear cell therapy in ischaemic stroke: a systematic review. Acta Neurol Scand. 2017; 135(5):496-506.

3. Cao W, Li P. Effectiveness and safety of autologous bone marrow stromal cells transplantation after ischemic stroke: a meta-analysis. Med Sci Monit. 2015;21:2190-2195.
4. Reis C, Wilkinson M, Reis H, et al. A look into stem cell therapy: exploring the options for treatment of ischemic stroke. Stem Cells Int. 2017; 2017:3267352.

5. Hsuan YC, Lin CH, Chang CP, Lin MT. Mesenchymal stem cell-based treatments for stroke, neural trauma, and heat stroke. Brain Behav. 2016;6(10):e00526.

6. Zhou M, Wang H, Zhu J, et al. Cause-specific mortality for 240 causes in China during 1990-2013: a systematic subnational analysis for the Global Burden of Disease Study 2013. Lancet. 2016;387(10015): 251-272.

7. Cramer SC, Stradling D, Brown DM, et al. Organization of a United States county system for comprehensive acute stroke care. Stroke. 2012; 43(4):1089-1093.

8. Banerjee S, Bentley P, Hamady M, et al. Intra-arterial immunoselected CD34+ stem cells for acute ischemic stroke. Stem Cells Transl Med. 2014;3(11):1322-1330.

9. Boy S, Sauerbruch S, Kraemer M, et al. Mobilisation of hematopoietic CD34+ precursor cells in patients with acute stroke is safe - results of an open-labeled non randomized phase I/II trial. PLoS One. 2011; 6(8):e23099.

10. Kalladka D, Sinden J, Pollock K, et al. Human neural stem cells in patients with chronic ischaemic stroke (PISCES): a phase 1, first-in-man study. Lancet. 2016;388(10046):787-796. 
11. Qiao LY, Huang FJ, Zhao M, et al. A two-year follow-up study of cotransplantation with neural stem/progenitor cells and mesenchymal stromal cells in ischemic stroke patients. Cell Transplant. 2014;23 (Suppl 1): S65-S72.

12. Liao S, Luo C, Cao B, et al. Endothelial progenitor cells for ischemic stroke: update on basic research and application. Stem Cells Int. 2017; 2017:2193432.

13. Hess DC, Wechsler LR, Clark WM, et al. Safety and efficacy of multipotent adult progenitor cells in acute ischaemic stroke (MASTERS): a randomised, double-blind, placebo-controlled, phase 2 trial. Lancet Neurol. 2017;16(5):360-368.

14. Prasad K, Sharma A, Garg A, et al. Intravenous autologous bone marrow mononuclear stem cell therapy for ischemic stroke: a multicentric, randomized trial. Stroke. 2014;45(12):3618-3624.

15. Zhou C, Yang B, Tian Y, et al. Immunomodulatory effect of human umbilical cord Wharton's jelly-derived mesenchymal stem cells on lymphocytes. Cell Immunol. 2011;272(1):33-38.

16. Ghorbani S, Tiraihi T, Soleimani M. Differentiation of mesenchymal stem cells into neuron-like cells using composite 3D scaffold combined with valproic acid induction. J Biomater Appl. 2018;32(6):702-715.

17. Sarmah D, Agrawal V, Rane P, et al. Mesenchymal stem cell therapy in ischemic stroke: a meta-analysis of preclinical studies. Clin Pharmacol Ther. Epub 2017 Nov 1.

18. Sammali E, Alia C, Vegliante G, et al. Intravenous infusion of human bone marrow mesenchymal stromal cells promotes functional recovery and neuroplasticity after ischemic stroke in mice. Sci Rep. 2017; 7(1):6962.

19. Sasaki Y, Sasaki M, Kataoka-Sasaki Y, et al. Synergic effects of rehabilitation and intravenous infusion of mesenchymal stem cells after stroke in rats. Phys Ther. 2016;96(11):1791-1798.

20. Rosado-de-Castro PH, Pimentel-Coelho PM, da Fonseca LM, de Freitas GR, Mendez-Otero R. The rise of cell therapy trials for stroke: review of published and registered studies. Stem Cells Dev. 2013; 22(15):2095-2111.

21. Zeng X, Zhang Y, Kwong JS, et al. The methodological quality assessment tools for preclinical and clinical studies, systematic review and meta-analysis, and clinical practice guideline: a systematic review. J Evid Based Med. 2015;8(1):2-10.

22. Jackson D, White IR, Riley RD. Quantifying the impact of betweenstudy heterogeneity in multivariate meta-analyses. Stat Med. 2012; 31(29):3805-3820.

23. Bang OY, Lee JS, Lee PH, Lee G. Autologous mesenchymal stem cell transplantation in stroke patients. Ann Neurol. 2005;57(6):874-882.

24. Bhasin A, Padma Srivastava MV, Mohanty S, Bhatia R, Kumaran SS, Bose S. Stem cell therapy: a clinical trial of stroke. Clin Neurol Neurosurg. 2013;115(7):1003-1008.

25. Bhasin A, Kumaran SS, Bhatia R, Mohanty S, Srivastava MVP. Safety and feasibility of autologous mesenchymal stem cell transplantation in chronic stroke in Indian patients. A four-year follow up. J Stem Cells Regen Med. 2017;13(1):14-19.

26. Cai MS, Shen CL, Zeng LH, Huang XQ, Song CW. Effect of stem cell transplantation on serum homocysteine, CRP and BDNF in patients with ischemic stroke. Chin J Biochem Pharm. 2015;35(9):91-93.

27. Cheng Y, Wang D, Liu HB. Bone marrow mesenchymal stem cells transplantation in the recovery phase of ischemic cerebral stroke patients. Chin J Transplant. 2013;7(3):141-144.

28. Chen WD, Li JT, Zhang XB, et al. Clinical analysis of bone marrow mesenchymal stem cells transplantation in the treatment of cerebral infarction. Jilin Med J. 2012;33(21):4522.

29. Chen WM, Zou QY, Lu JJ, et al. Reinfusion of autologous bone marrow mesenchymal stem cells for treatment of stroke in 30 cases. Chin J Tissue Eng Res. 2012;16(32):6071-6075.

30. Deng YG, Zhang ZP, Yu W. Clinical efficacy of salvia miltiorrhiza injection combined with marrow stem cells in treatment of cerebral infarction. Pract J Cardiac Cereb Pneumal Vasc Dis. 2012;20(3):424-425.

31. Feng Y, Tian GP, Li L, Zhou J. Effect of human umbilical cord bloodderived mesenchymal stem cells in the treatment of cerebral infarction. Pract J Cardiac Cereb Pneumal Vasc Dis. 2014;22(1):28-30.
32. He ZD. The functional mechanism of mesenchymal stem cell transplantation therapy for patients with cerebral infarction. Asia Pac Tradit Med. 2012;8(12):126-127.

33. Hu Q, Cao MY, Li RF, Jiang HW, Ge LT. Safety and efficacy on the treatment of cerebral infarction with umbilical cord mesenchymal stem cells. Med J Wuhan Univ. 2013;34(1):57-70.

34. Ji X, Zhao HT, Zhang XB, et al. Clinical analysis of mesenchymal stem cells for treatment of stroke in 60 cases. J Xianning Univ. 2012; 26(1):31-32

35. Lee JS, Hong JM, Moon GJ, Lee PH, Ahn YH, Bang OY. A long-term follow-up study of intravenous autologous mesenchymal stem cell transplantation in patients with ischemic stroke. Stem Cells. 2010;28(6): 1099-1106.

36. Liu DH, Han BJ, Hong SS, et al. Transplanting autologous mesenchymal nerve stem cells in the treatment of cerebral infarction. Chin J Phys Med Rehabil. 2014;36(6):425-428.

37. Meng XG, Zhu SW, Gao H, et al. Treatment of cerebral infarction using autologous marrow mesenchymal stem cells transplantation: a six-month follow-up. J Clin Rehabil Tissue Eng Res. 2009;13(32):6374-6378.

38. Shen DP. Umbilical cord mesenchymal stem cell early single transplantation in treatment of neurological recovery in acute cerebral infarction. Chin J Trauma Disabil Med. 2015;23(2):26-28.

39. Song CW, Wang $\mathrm{P}, \mathrm{Hu} X \mathrm{XQ}$, et al. Clinical efficacy of umbilical cord blood mesenchymal stem cells transplantation in the treatment of cerebral infarction. J Clin Ration Drug Use. 2013;6(2):69-70.

40. Sun HB, Xia SM, Yang SS. The clinical effect of rhG-CSF combined transplantation of autologous bone marrow mesenchymal stem cells on acute cerebral infarction. J Chin Phys. 2008;10(4):441-443.

41. Sun SC, Wang C, Luo JS. Bone marrow mesenchymal stem cell transplantation improved the neurological function of 35 patients with sequelae of stroke. China Med Eng. 2013;21(6):14-17.

42. Tsang KS, Ng CPS, Zhu XL, et al. Phase I/II randomized controlled trial of autologous bone marrow-derived mesenchymal stem cell therapy for chronic stroke. World J Stem Cells. 2017;9(8):133-143.

43. Wang X, Zhang ZB, Jia FR, Yang H. A clinical study on treatment of cerebral infarction using autologous marrow mesenchymal stem cells intervening transplantation. Jilin Med J. 2014;35(2):237-239.

44. Xie XF, Liu SY, Jin GH, Qu XH, Zhang KN, Wu XM. Clinical analysis of autologous bone marrow mesenchymal stem cell transplantation for treating cerebral infarction. Lab Med Clin. 2014;11(21):2955-5957.

45. Zhao XL, Wang Y, Zhang CX, Tan J. Study of bone marrow mesenchymal stem cells in the treatment of stroke. Global Chin Med. 2013; 6(S2): 157.

46. Borlongan CV, Glover LE, Tajiri N, Kaneko Y, Freeman TB. The great migration of bone marrow-derived stem cells toward the ischemic brain: therapeutic implications for stroke and other neurological disorders. Prog Neurobiol. 2011;95(2):213-228.

47. Zacharek A, Shehadah A, Chen J, et al. Comparison of bone marrow stromal cells derived from stroke and normal rats for stroke treatment. Stroke. 2010;41(3):524-530.

48. Wakabayashi K, Nagai A, Sheikh AM, et al. Transplantation of human mesenchymal stem cells promotes functional improvement and increased expression of neurotrophic factors in a rat focal cerebral ischemia model. J Neurosci Res. 2010;88(5):1017-1025.

49. Lanza C, Morando S, Voci A, et al. Neuroprotective mesenchymal stem cells are endowed with a potent antioxidant effect in vivo. J Neurochem. 2009;110(5):1674-1684.

50. Hokari M, Kuroda S, Shichinohe H, Yano S, Hida K, Iwasaki Y. Bone marrow stromal cells protect and repair damaged neurons through multiple mechanisms. J Neurosci Res. 2008;86(5):1024-1035.

51. Onda T, Honmou O, Harada K, Houkin K, Hamada H, Kocsis JD Therapeutic benefits by human mesenchymal stem cells (hMSCs) and Ang-1 gene-modified hMSCs after cerebral ischemia. J Cereb Blood Flow Metab. 2008;28(2):329-340.

52. Lin BL, Chen JF, Qiu WH, et al. Allogeneic bone marrow-derived mesenchymal stromal cells for hepatitis B virus-related acute-on-chronic liver failure: a randomized controlled trial. Hepatology. 2017;66(1): 209-219. 
53. Ahn SY, Chang YS, Kim JH, Sung SI, Park WS. Two-year follow-up outcomes of premature infants enrolled in the phase I trial of mesenchymal stem cells transplantation for bronchopulmonary dysplasia. J Pediatr. 2017;185:49.e2-54.e2.

54. Zhang YC, Liu W, Fu BS, et al. Therapeutic potentials of umbilical cordderived mesenchymal stromal cells for ischemic-type biliary lesions following liver transplantation. Cytotherapy. 2017;19(2):194-199.

55. Wang H, Li Y, Wu Q, Xu C, Liu Q. Combination of butylphthalide with umbilical mesenchymal stem cells for the treatment of delayed encephalopathy after carbon monoxide poisoning. Medicine. 2016; 95(49):e5412.

56. Losordo DW, Henry TD, Davidson C, et al. Intramyocardial, autologous CD34+ cell therapy for refractory angina. Circ Res. 2011;109(4): $428-436$.
57. Jeong H, Yim HW, Cho YS, et al. Efficacy and safety of stem cell therapies for patients with stroke: a systematic review and single arm meta-analysis. Int J Stem Cells. 2014;7(2):63-69.

58. Wan H, Li F, Zhu L, Wang J, Yang Z, Pan Y. Update on therapeutic mechanism for bone marrow stromal cells in ischemic stroke. $J \mathrm{Mol}$ Neurosci. 2014;52(2):177-185.

59. Yang B, Strong R, Sharma S, et al. Therapeutic time window and dose response of autologous bone marrow mononuclear cells for ischemic stroke. J Neurosci Res. 2011;89(6):833-839. 


\section{Supplementary materials}

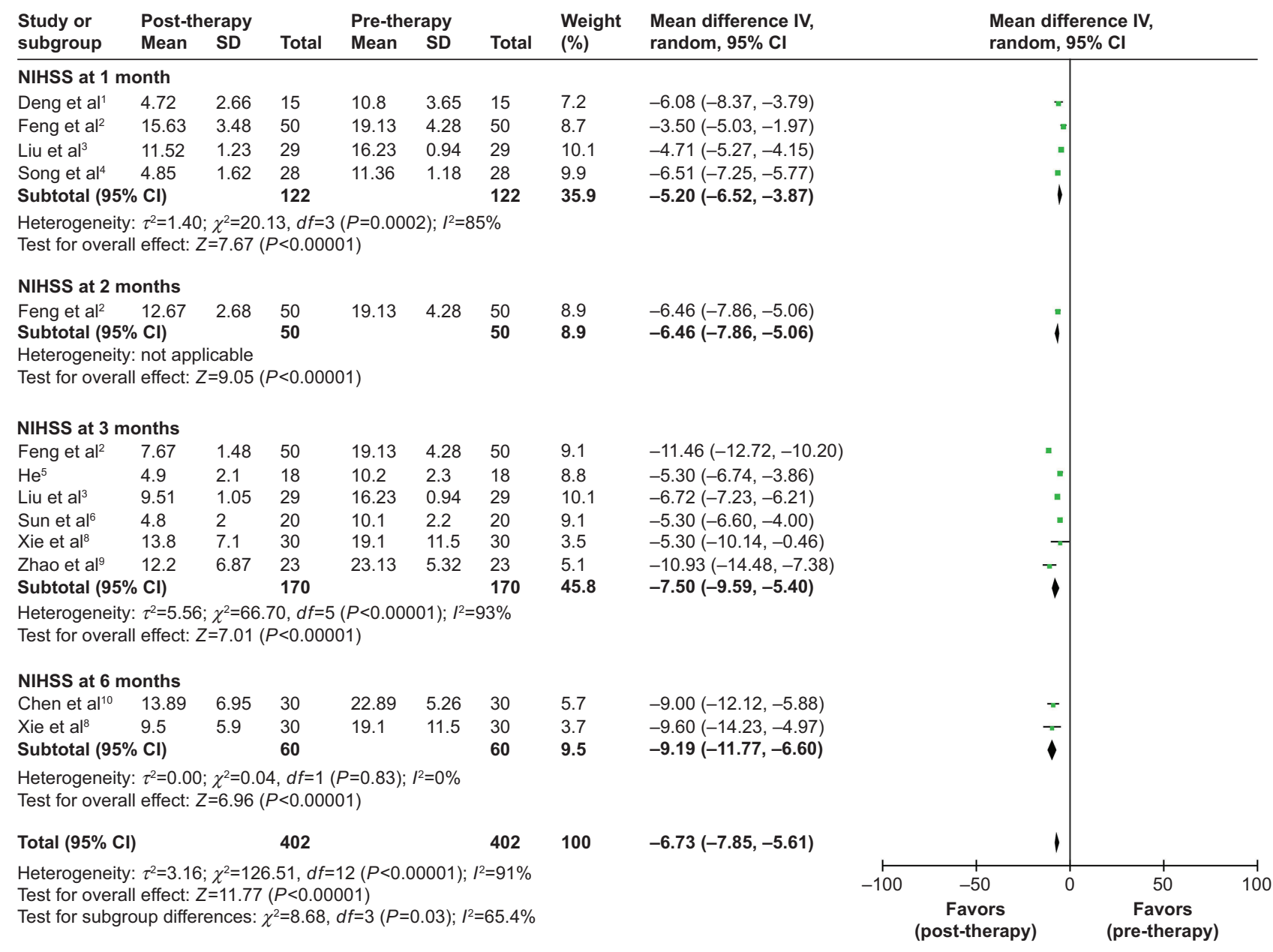

Figure SI Forest plot of the comparison of NIHSS scores pre- and post-therapy.

Note: The random-effects meta-analysis model (inverse variance method) was used.

Abbreviations: IV, inverse variance; NIHSS, National Institutes of Health Stroke Scale. 


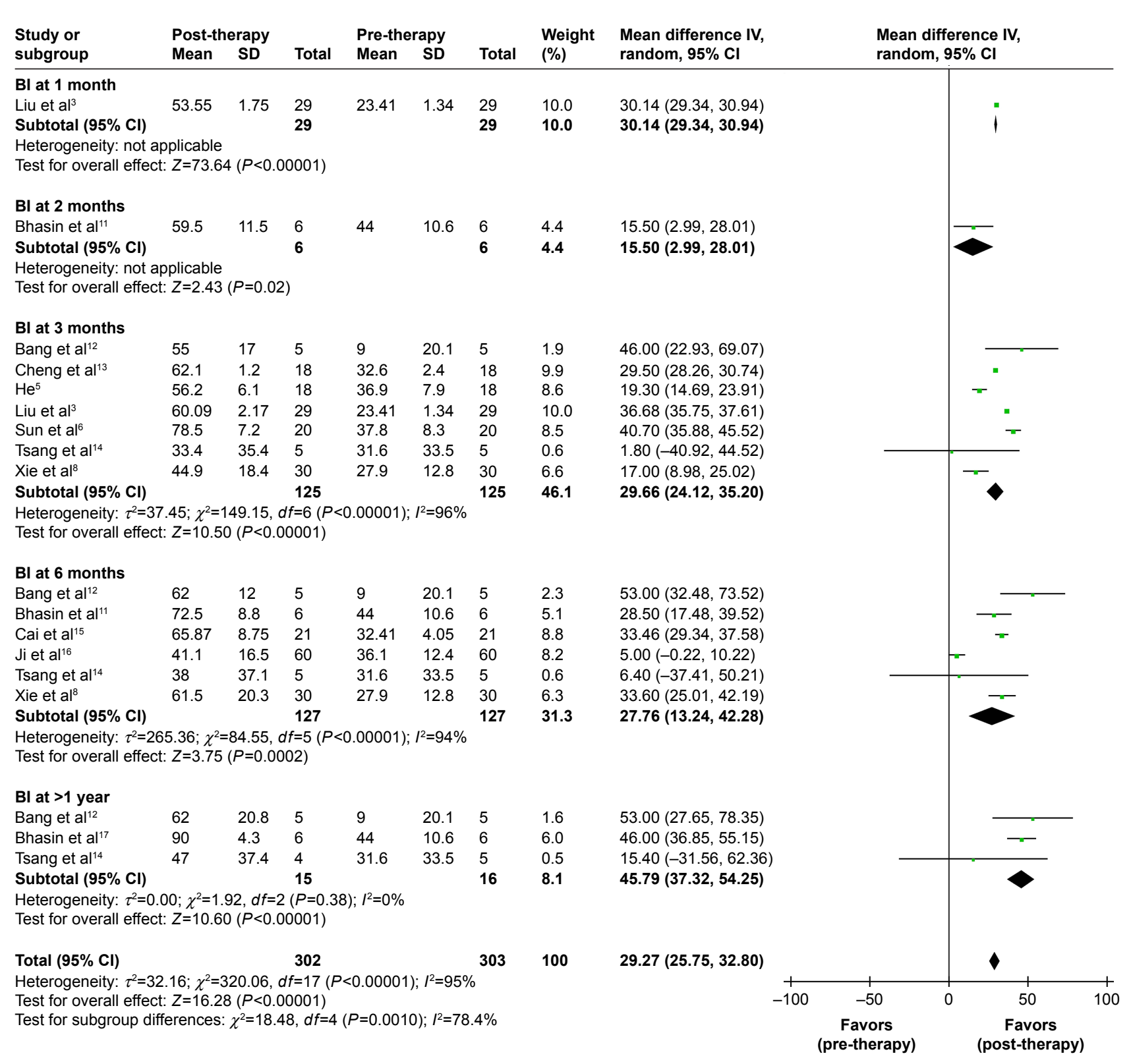

Figure S2 Forest plot of the comparison of Bl scores pre- and post-therapy.

Note: The random-effects meta-analysis model (inverse variance method) was used.

Abbreviations: IV, inverse variance; BI, Barthel index. 


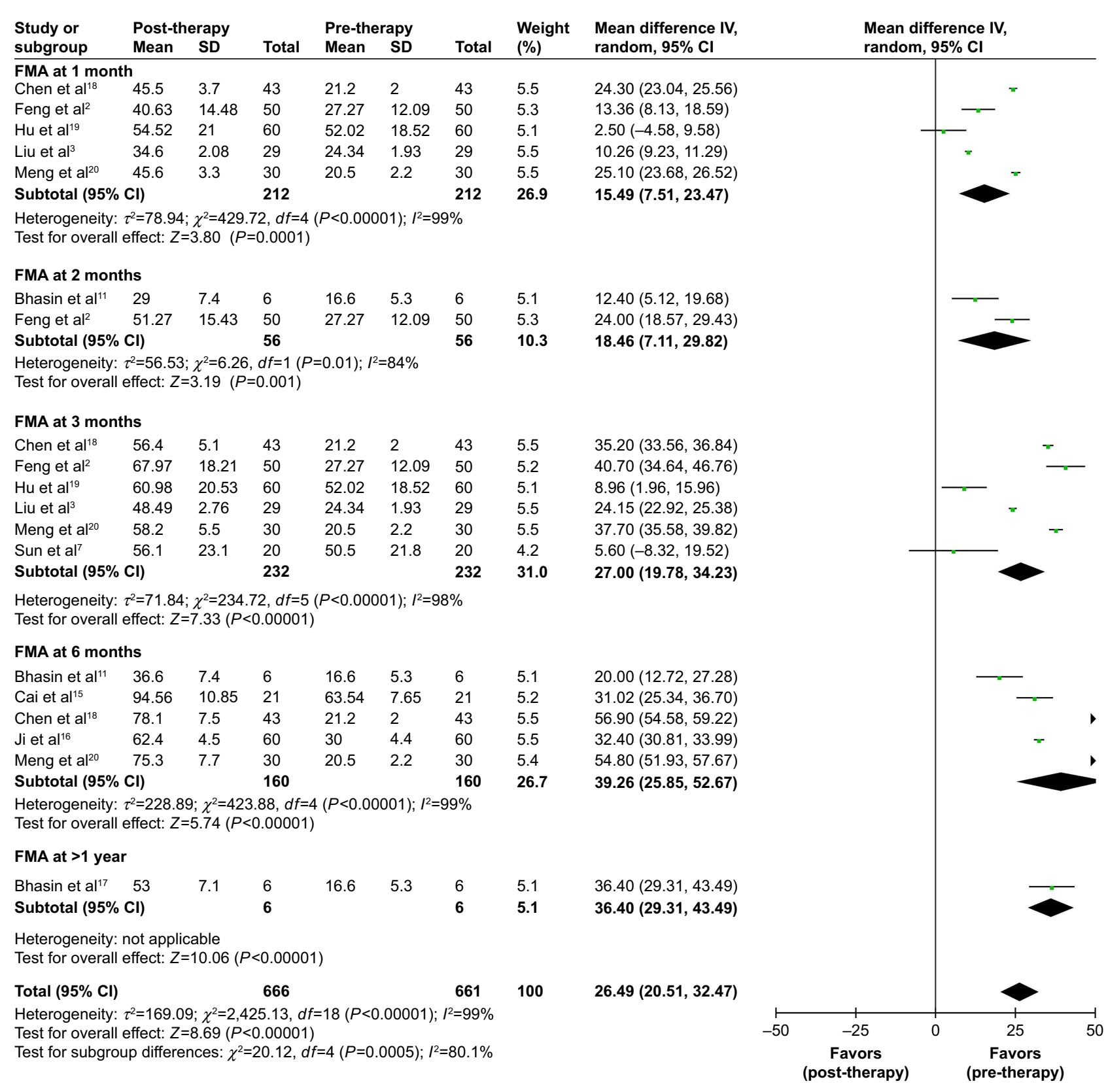

Figure S3 Forest plot of the comparison of FMA scores pre- and post-therapy.

Note: The random-effects meta-analysis model (inverse variance method) was used.

Abbreviations: IV, inverse variance; FMA, Fugl-Meyer Assessment. 


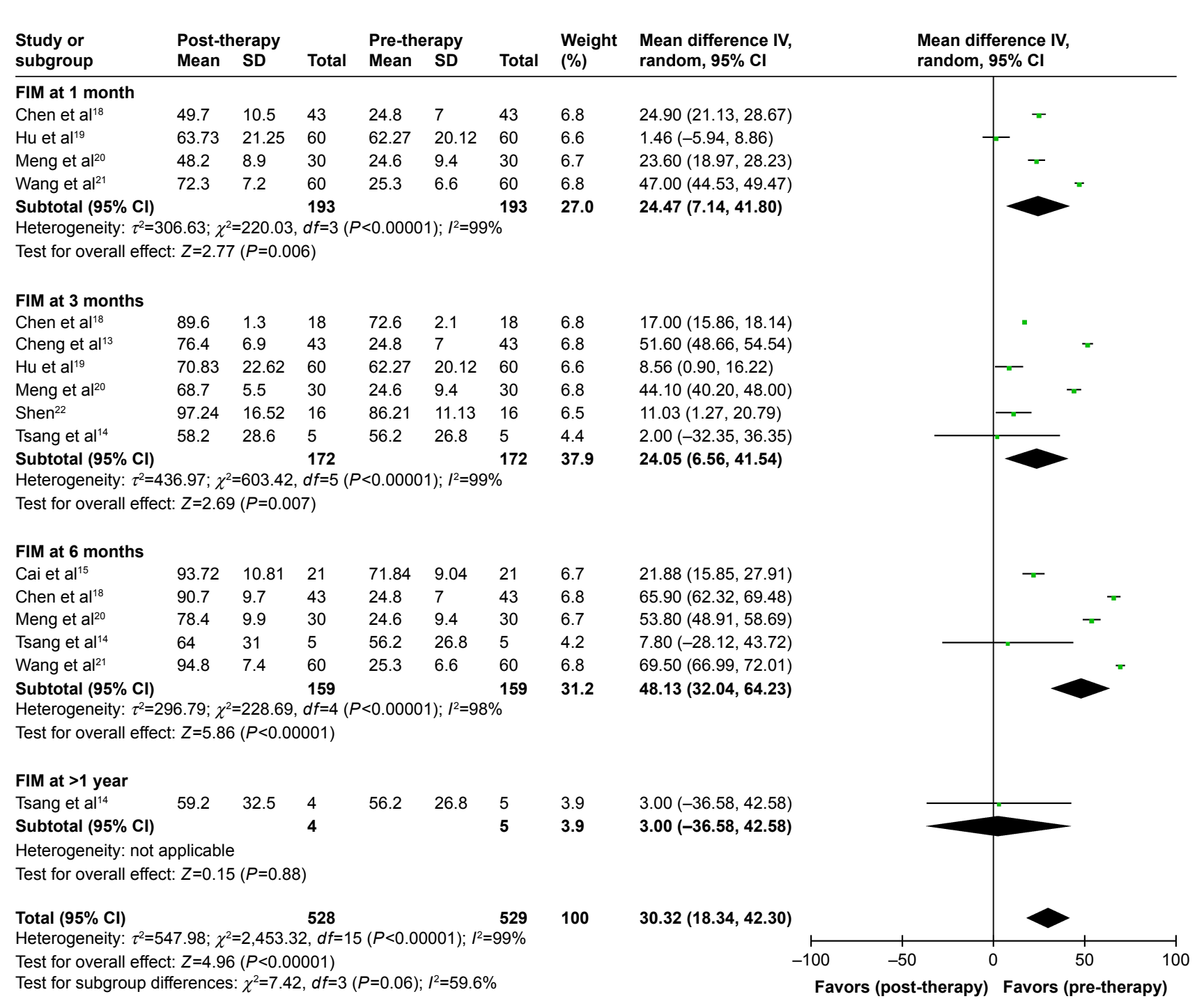

Figure S4 Forest plot of the comparison of FIM scores in pre- and post-therapy.

Note: The random-effects meta-analysis model (inverse variance method) was used. Abbreviations: IV, inverse variance; FIM, Functional Independence Measure. 

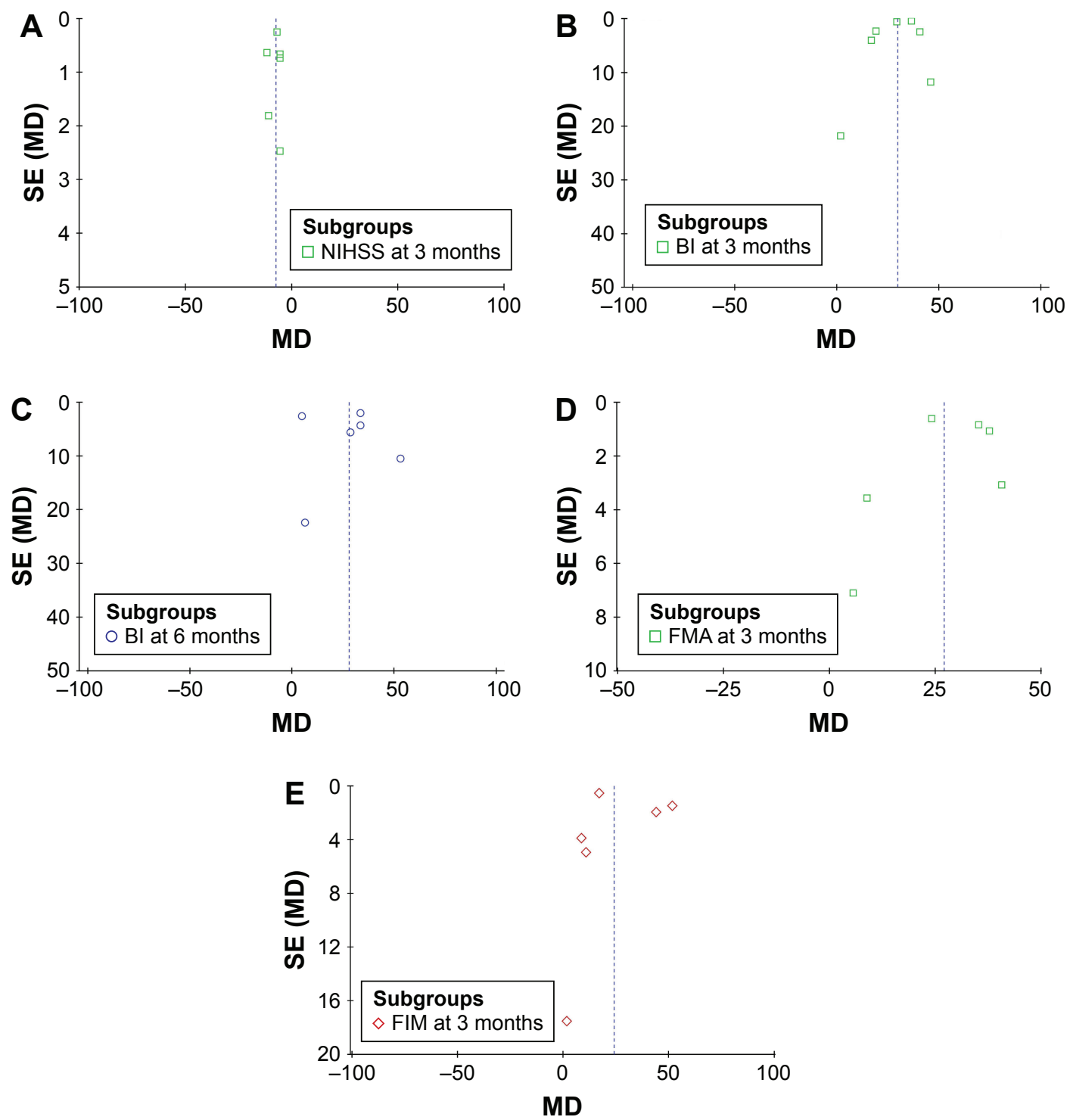

Figure S5 Funnel plot of the NIHSS (A), BI (B and C), FMA (D) and FIM (E) scores pre- and post-therapy.

Note: Parameters were discussed in over five studies which were included in bias analyses.

Abbreviations: SE, standard error; MD, mean deviation; NIHSS, National Institutes of Health Stroke Scale; BI, Barthel index; FMA, Fugl-Meyer Assessment; FIM, Functional Independence Measure.

\section{References}

1. Deng YG, Zhang ZP, Yu W. Clinical efficacy of salvia miltiorrhiza injection combined with marrow stem cells in treatment of cerebral infarction. Pract J Cardiac Cereb Pneumal Vasc Dis. 2012;20(3):424-425.

2. Feng Y, Tian GP, Li L, Zhou J. Effect of human umbilical cord bloodderived mesenchymal stem cells in the treatment of cerebral infarction. Pract J Cardiac Cereb Pneumal Vasc Dis. 2014;22(1):28-30.

3. Liu DH, Han BJ, Hong SS, et al. Transplanting autologous mesenchymal nerve stem cells in the treatment of cerebral infarction. Chin J Phys Med Rehabil. 2014;36(6):425-428.

4. Song CW, Wang P, Hu XQ, et al. Clinical efficacy of umbilical cord blood mesenchymal stem cells transplantation in the treatment of cerebral infarction. J Clin Ration Drug Use. 2013;6(2):69-70.

5. He ZD. The functional mechanism of mesenchymal stem cell transplantation therapy for patients with cerebral infarction. Asia Pac Tradit Med. 2012;8(12):126-127.
6. Sun HB, Xia SM, Yang SS. The clinical effect of rhG-CSF combined transplantation of autologous bone marrow mesenchymal stem cells on acute cerebral infarction. J Chin Phys. 2008;10(4):441-443.

7. Sun SC, Wang C, Luo JS. Bone marrow mesenchymal stem cell transplantation improved the neurological function of 35 patients with sequelae of stroke. China Med Eng. 2013;21(6):14-17.

8. Xie XF, Liu SY, Jin GH, Qu XH, Zhang KN, Wu XM. Clinical analysis of autologous bone marrow mesenchymal stem cell transplantation for treating cerebral infarction. Lab Med Clin. 2014;11(21): 2955-5957.

9. Zhao XL, Wang Y, Zhang CX, Tan J. Study of bone marrow mesenchymal stem cells in the treatment of stroke. Global Chin Med. 2013;6(S2):157.

10. Chen WM, Zou QY, Lu JJ, et al. Reinfusion of autologous bone marrow mesenchymal stem cells for treatment of stroke in 30 cases. Chin J Tissue Eng Res. 2012;16(32):6071-6075. 
11. Bhasin A, Padma Srivastava MV, Mohanty S, Bhatia R, Kumaran SS, Bose S. Stem cell therapy: a clinical trial of stroke. Clin Neurol Neurosurg. 2013;115(7):1003-1008.

12. Bang OY, Lee JS, Lee PH, Lee G. Autologous mesenchymal stem cell transplantation in stroke patients. Ann Neurol. 2005;57(6):874-882.

13. Cheng Y, Wang D, Liu HB. Bone marrow mesenchymal stem cells transplantation in the recovery phase of ischemic cerebral stroke patients. Chin J Transplant. 2013;7(3):141-144.

14. Tsang KS, Ng CPS, Zhu XL, et al. Phase I/II randomized controlled trial of autologous bone marrow-derived mesenchymal stem cell therapy for chronic stroke. World J Stem Cells. 2017;9(8):133-143.

15. Cai MS, Shen CL, Zeng LH, Huang XQ, Song CW. Effect of stem cell transplantation on serum homocysteine, CRP and BDNF in patients with ischemic stroke. Chin J Biochem Pharm. 2015;35(9):91-93.

16. Ji X, Zhao HT, Zhang XB, et al. Clinical analysis of mesenchymal stem cells for treatment of stroke in 60 cases. J Xianning Univ. 2012; 26(1):31-32.

17. Bhasin A, Kumaran SS, Bhatia R, Mohanty S, Srivastava MVP. Safety and feasibility of autologous mesenchymal stem cell transplantation in chronic stroke in Indian patients. A four-year follow up. J Stem Cells Regen Med. 2017;13(1):14-19.
18. Chen WD, Li JT, Zhang XB, et al. Clinical analysis of bone marrow mesenchymal stem cells transplantation in the treatment of cerebral infarction. Jilin Med J. 2012;33(21):4522.

19. Hu Q, Cao MY, Li RF, Jiang HW, Ge LT. Safety and efficacy on the treatment of cerebral infarction with umbilical cord mesenchymal stem cells. Med J Wuhan Univ. 2013;34(1):57-70.

20. Meng XG, Zhu SW, Gao H, et al. Treatment of cerebral infarction using autologous marrow mesenchymal stem cells transplantation: a six-month follow-up. J Clin Rehabil Tissue Eng Res. 2009;13(32):6374-6378.

21. Wang X, Zhang ZB, Jia FR, Yang H. A clinical study on treatment of cerebral infarction using autologous marrow mesenchymal stem cells intervening transplantation. Jilin Med J. 2014;35(2):237-239.

22. Shen DP. Umbilical cord mesenchymal stem cell early single transplantation in treatment of neurological recovery in acute cerebral infarction. Chin J Trauma Disabil Med. 2015;23(2):26-28.
Therapeutics and Clinical Risk Management

\section{Publish your work in this journal}

Therapeutics and Clinical Risk Management is an international, peerreviewed journal of clinical therapeutics and risk management, focusing on concise rapid reporting of clinical studies in all therapeutic areas, outcomes, safety, and programs for the effective, safe, and sustained use of medicines. This journal is indexed on PubMed Central, CAS,

\section{Dovepress}

EMBase, Scopus and the Elsevier Bibliographic databases. The manuscript management system is completely online and includes a very quick and fair peer-review system, which is all easy to use. Visit $\mathrm{http}: / / \mathrm{www}$.dovepress.com/testimonials.php to read real quotes from published authors.

Submit your manuscript here: http://www.dovepress.com/therapeutics-and-clinical-risk-management-journal 